\title{
Data Collection, Validation, and Description for the Oak Ridge Nuclear Facilities Mortality Study
}

\author{
J. P. Watkins, ${ }^{1}$ J. L. Reagan, ${ }^{1,2}$ D. L. Cragle, ${ }^{1}$ E. L. Frome, ${ }^{3}$ \\ C. M. West, ${ }^{1}$ D. J. Crawford-Brown, ${ }^{4}$ and W. G. Tankersley ${ }^{1}$
}

${ }^{1}$ Oak Ridge Institute for Science and Education, Center for Epidemiologic Research, Oak Ridge, TN 37831-0117.

${ }^{2}$ Current address: Science Applicatjons International Corporation, Oak Ridge, TN 37831. ${ }^{3}$ Oak Ridge National Laboratory, Oak Ridge, TN 37830.

${ }^{4}$ School of Public Health, University of North Carolina, Chapel Hill, NC 27599-7400.

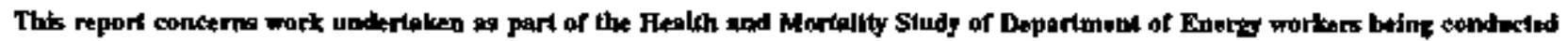

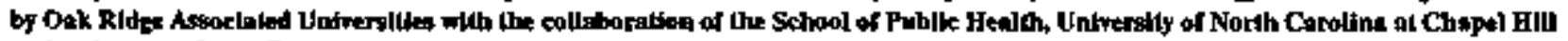

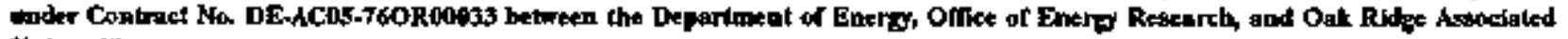
Untversilies.

Available to the public from the National Tochnical Infomiation Service, U.S. Department of Comfnerce, 5825 Port Royal Rd., SpringEeld, VA 22161

Price: Printed Copy A04 Microfiche A01 


\section{DISCLAIMER}

Portions of this document may be illegible in electronic image products. Images are produced from the best available original document. 


\section{EXECUTIVE SUMMARY}

To investigate the long-term health effects of protracted occupational exposure to low levels of ionizing radiation, a mortality stươy was initiated by pooling data for 118,588 workers hired between 1943 and 1982, at three Department of Energy (DOE) facilities in Oak Ridge, Tennessee, with follow-up through 1984. Topics for this discussion will include issues involving the collection and validation of data for individuals in the study cohort, and characteristics of their demographic and radiation exposure data. Since the data were compiled between the late 1960 s and the present under the direction of several principal investigators, it was essential to verify data precision and to understand how exposure data were generated prior to beginning any analysis. A stratifjed random sample of workers in the cohort was chosen for verification of their computerized data as it appeared in the database. Original source documents were reviewed to verify demographic data, as well as internal and external radiation exposure data. Extensive effort was expended to document the personal radiation monitoring policies and types of dosimeters used at each facility over the 42 years included in the study. Characteristics of internal and external exposure data by facility and year were examined by graphical methods with the intent of combining these monitoring data over time and across facilities. One result of the data validation procedures was the decision to limit the portion of the analyses that included radiation monitoring data to a subcohort of 28,347 white males who had ever been employed by the Oak Ridge National Laboratory (ORNL) or by the Y-12 facility after mid-1947 and so were potentially exposed to external radiation. This subcohort received $36,725 \mathrm{cSv}$ (over $90 \%$ ) of the total dose recorded for the cohort and had more complete follow-up than the other three 
race/gender groups (nonwhite males, white fenales, nonwhite females). Another result was an awareness of possible bias in the recorded annual external doses, particutarly from early years of plant operation. At ORNL film badges were read weekly from mid-1944 through mid-1956, and readings below the threshold value were generally set to zero. Although this frequency of reading helped to insure that more highly exposed workers were identiffed quickly, it also may have caused an underestimation of dose among workers whose monitored values did not reach the threshold bevel in just one week. In addition, the policy at the Y-12 facility from 1948 until 1961 was to monitor with film badges only those workers who were considered to be at risk for radiation exposure. This practice resulted in over 85 percent nonmonitored person-years during this period when the maximum allowable dose was $0.3 \mathrm{cSv} /$ week ( $15 \mathrm{cSv} / \mathrm{year}$ ) as contrasted with the current maximum allowable dose of 5 cSv/year. Therefore, to compensate for underreported dose, we are developing a second set of doses, containing upward adjustments for certain years in ORNL and $Y-12$, to estimate doses actually received. K-25 doses were not adjusted because of lack of monitoring data. Details on the dose adjustment procedures will appear in a supplement to this report. Results of all analyses are to be presented in a separate report.

\section{DISCLAIMER}

This repoet was prepared at an accoust of wotk aponsored by an agancy of the United Stutes Gowernment. Neither the United States Gowerament mor any agency thereof, ar any of their expptoyces, makes any warranty, express of implied, or assunes any logal liability of responsi-

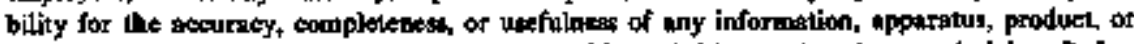
process ditckesed, or reptesents that its wse would not infrintse privately ownod rifhts. Reles-

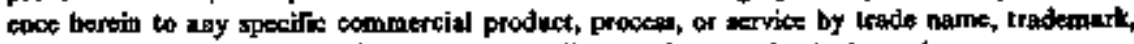

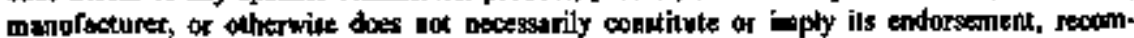

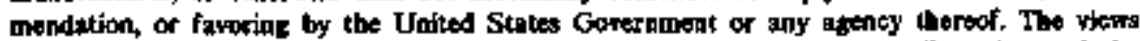

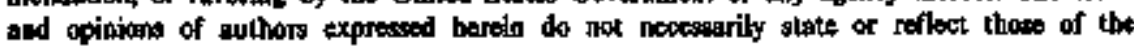
United States Goverument of any ageacy thereof. 


\section{TABLE OF CONTENTS}

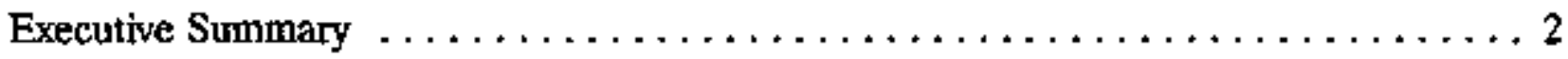

Introduction $\ldots \ldots \ldots \ldots \ldots \ldots \ldots \ldots \ldots \ldots \ldots \ldots \ldots \ldots \ldots \ldots \ldots$

Background $\ldots \ldots \ldots \ldots \ldots \ldots \ldots \ldots \ldots \ldots \ldots \ldots \ldots \ldots \ldots$

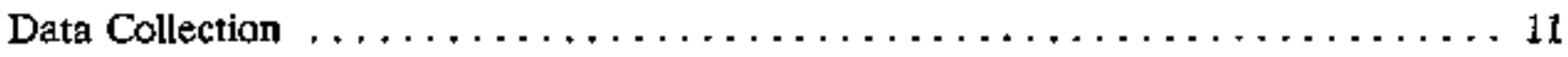

Compiling and Checking the Rosters $\ldots \ldots \ldots \ldots \ldots \ldots \ldots \ldots \ldots \ldots 11$

Data Management at ORISE $\ldots \ldots \ldots \ldots \ldots \ldots \ldots \ldots \ldots \ldots \ldots \ldots \ldots$

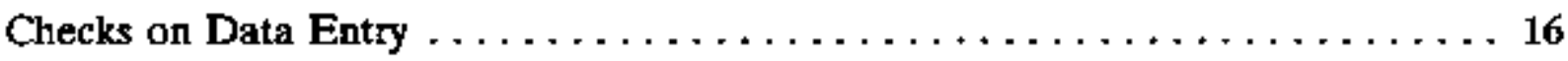

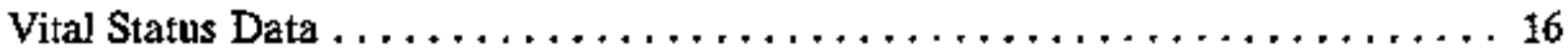

Creation of Analysis Files $\ldots \ldots \ldots \ldots \ldots \ldots \ldots \ldots \ldots \ldots \ldots \ldots \ldots \ldots$

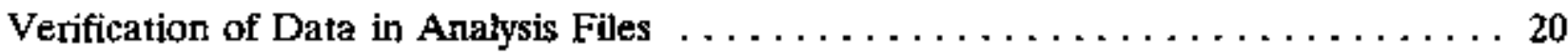

Description of Data for the Study Population $\ldots \ldots \ldots \ldots \ldots \ldots \ldots \ldots \ldots \ldots$

Demographic Characteristics of the Study Cohort $\ldots \ldots \ldots \ldots \ldots \ldots \ldots$

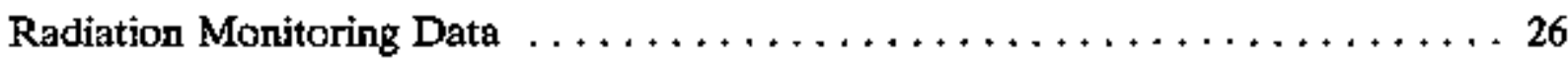

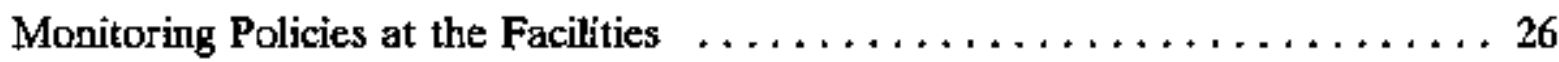

External Radiation Dose $\ldots \ldots \ldots \ldots \ldots \ldots \ldots \ldots \ldots \ldots \ldots \ldots \ldots$

Internal Radiation Exposure $\ldots \ldots \ldots \ldots \ldots \ldots \ldots \ldots \ldots \ldots \ldots \ldots \ldots \ldots$

Monitoring Data Characteristics of the Study Cohort $\ldots \ldots \ldots \ldots \ldots \ldots$

Discussion $\ldots \ldots \ldots \ldots \ldots \ldots \ldots \ldots \ldots \ldots \ldots \ldots \ldots \ldots \ldots \ldots \ldots \ldots, 41$

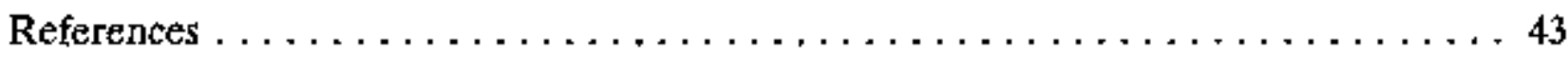

Appendix A: Subcohort for Facility Comparison Analysis $\ldots \ldots \ldots \ldots \ldots \ldots \ldots$ 48

Appendix B: Subcohort for Dose-Response Avalysis $\ldots \ldots \ldots \ldots \ldots \ldots \ldots \ldots 4$ 


\section{LIST OF TABLES AND FIGURES}

\section{Text Tables}

Table 1 Workers on Rosters Who Were Eliminated from Study Cohort ... . . 19

Table 2 Results of Data Verification from Random Sample $\ldots \ldots \ldots \ldots \ldots 21$

Table 3 Demographic Data Information on the Study Cohort $\ldots \ldots \ldots \ldots 25$

Table 4 Inventory of Radionuclides by Facility $\ldots \ldots \ldots \ldots \ldots \ldots \ldots \ldots$

Table 5 Monitoring Data Information on the Study Cohort $\ldots \ldots \ldots \ldots \ldots 35$

\section{Text Figures}

Figure 1 Comparison of Annual Employment Figures $\ldots \ldots \ldots \ldots \ldots \ldots$ i3

Figure 2 Comparison of Cumulative External Dose through $1984 \ldots \ldots \ldots \ldots 22$

Figure 3 Personal Monitoring Policies for Oak Ridge Workers by Plant, 1943-1984

Figure 4 Types of Dosimeters and Frequency of Readings for Oak Ridge

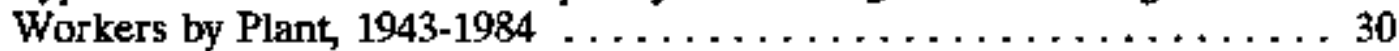

Figure 5 Total Annual External Dose by Facility $\ldots \ldots \ldots \ldots \ldots \ldots$

Figute 6 Percent Monitored for External Dose by Facility $\ldots \ldots \ldots \ldots \ldots$. . . . 39

Figure 7 Percent Monitored for Internal Exposure by Facility $\ldots \ldots \ldots \ldots 40$

Appendix Tables

Table A1: Impact of 365 Day Entry to Follow-up $\ldots \ldots \ldots \ldots \ldots \ldots \ldots$. 49

Table A2: Distribution of Covariables by Race/Gender Groups . . . . . . . . 49

Table A3: Average Years of Employment and Follow-up by Race/Gender Groups . . . . . . . . . . . . . . . . . 50

Table A4: Paycode by Facility of First Hire (White Males) $\ldots \ldots \ldots \ldots \ldots, 50$

Table A5: Length of Employment by Facility of First Hire (White Males) . . . . 50 
Table A6: Paycode by Facility of First Hire (Nonwhite Males) $\ldots \ldots \ldots \ldots \$ 1$

Table A7: Length of Employment by Facility of Fïrst Hire (Nonwhite Males) . 51

Table A8: Paycode by Facility of First Hire (White Females) $\ldots \ldots \ldots \ldots 52$

Table A9: Length of Employment by Facility of First Hire (White Females) . . 52

Table A10: Paycode by Facility of First Hire (Nonwhite Females) $\ldots \ldots \ldots \ldots 53$

Table A11: Length of Employment by Facility of First Hire (Nonwhite Females) $\ldots \ldots \ldots \ldots \ldots \ldots \ldots \ldots \ldots \ldots \ldots, 53$

Table B1: Impact of 365 Day Entry to Follow-up $\ldots \ldots \ldots \ldots \ldots \ldots \ldots \ldots$

Table B2: Distribution of Covariables $\ldots \ldots \ldots \ldots \ldots \ldots \ldots \ldots \ldots \ldots, \ldots 5$

Table B3: Average Years of Employment and Follow-up $\ldots \ldots \ldots \ldots \ldots \ldots 5$

Table B4: Distribution by Facility $\ldots \ldots \ldots \ldots \ldots \ldots \ldots \ldots \ldots \ldots \ldots 6$

Table BS: Distribution of Unadjusted Extema! Doses with Lags . . . . . . . . 56

Table B6: Distribution of Annual Internal Exposure Values $\ldots \ldots \ldots \ldots \ldots$ s7 Appendix Figures

Figure B1: Percent of ORNL Workers Monitored $\ldots \ldots \ldots \ldots \ldots \ldots \ldots, 58$

Figure B2: Percent of $\mathrm{Y}-12$ Workers Monitored $\ldots \ldots \ldots \ldots \ldots \ldots \ldots \ldots$

Figure B3: Percent of ORNL Workers by Annual Internal Exposure Indicator . 60

Figure B4: Percent of Y-12 Workers by Annual Internal Exposure Indicator . . 61

Figure B5: Percent of K-25 Workers by Annual Internai Exposure Indicator $\ldots 62$ 


\section{INTRODUCTION}

To further investigate the long-term health effects of protracted occupational exposure to low levels of ionizing radiation, the Oak Ridge Facility Comparison Study (ORFCOM) was initiated to combine data on all workers employed by federal nuclear plants in Oak Ridge, Tennessee, and evaluate mortality with respect to facility of employment and occupational exposures. Numerous published studies have examined cause-specific mortality for single Oak Ridge plant populations (Carpenter et al., 1987; Checkoway et al., 1983; Checkoway et al., 1985; Checkoway et al., 1988; Cookfair, 1983; Cragle et al., 1984A; Cragle et al., 1984B; Cragle et al., 1992; Polednak, 1980A; Polednak, 1980B; Polednak and Frome, 1981; Polednak and Hollis, 1985; Wing et al, 1991). However, the ORFCOM project encompasses all workers, including those workers employed at multiple facilities, and therefore requires a uniform approach to radiation assessment applied across all facilities. Inclusion of multiple-facility workers increases the population size and population radiation dose, thus increasing the power of the study.

The project was planned in several phases in order to allow analyses to be conducted while the lengthy processes of data callection and validation, which included gathering of information on radiation monitoring, and radiation assessment were in progress. The project was planned in several phases. The first phase was restricted to white males who were employed for more than $\mathbf{3 0}$ days at any Oak Ridge facility and who terminated prior to January 1, 1948. These 'World War II' (WWII) workers were likely different from later employees because of conditions existing during the wartime era. Also, individual monitoring data for these workers were very sparse because radiation monitoring programs were only 
beginning. Results of the analysis of the WWII workers (Frome et al, 1991) showed an excess mortality primarily due to lung cancer and diseases of the respiratory system, and also a significant upward trend in the lung cancer standardized mortality ratio (SMR) by calendar period. The lung cancer increase was not found to be related to potential for radiation exposure; in analyses using Poisson modeling techniques socioeconomic status was the strongest predictor of mortality.

The current study inctudes workers of both genders and all races who were hired before January 1, 1983, were employed for at least 30 days, and whose data were free of critical errors. The primary objectives of this study are to evaluate and compare the mortality experience of workers in all Oak Ridge facilities and to conduct detailed doseresponse analyses for workers who were monitored for external exposure to radiation. Annual external radjation doses were calculated from individual monitoring results; for internal exposure an indicator variable was used to designate "exposed", "not exposed", or "not monitored" during each year of employment.

It was envisioned that when individual internal radiation doses had been calculated, an additional phase of the ORFCOM project could be conducted to examine the joint relationship of internal radiation exposure and external dose on mortality. The additional phase could also further investigate any questions raised by the current study, particularly in regards to dose adjustment and dose uncertainty.

The results of the analyses performed in the current study along with a summary of this report will be submitted to a peer-reviewed journal for publication. The purpose of this report is to discuss issues related to combining monitoring data over facilities and 
investigating the validity of the monitoring and other data. Descriptive statistics, tables, and graphs for all demographic, work history, and monitoring data are included to provide the framework necessary for the interpretation of the epidemiologic analyses on this study cohort. Extensive effort was required to document the monitoring policies used at each facility over the 42 years included in this study; charts are presented to summarize these policies. Graphs showing characteristics of external and internal dosimetry data by facility by year illustrate the complexities involved in combining monitoring data over time and across facilities. In addition to the unadjusted external doses, a second set of annual doses was calculated for individuals for years when dosimetry records were likely to have underestimated the actual external dose received. Methods used to obtain the replacement doses will be described in a supplement to this report.

\section{BACKGROUND}

The Oak Ridge facilities include the Oak Ridge National Laboratory (ORNL, also known as X-10), the Y-12 facility, and the K-25 facility (formerly the Oak Ridge Gaseous Diffusion Plant). ORNL began operation early in 1943 under the management of the University of Chicago to provide research and development for the atomic pile project and to produce small quantities of plutonium. In March of 1948 Union Carbjde Corporation Nuclear Division (UCCND) took over operations with the goal of providing the working environment necessary for pure research as well as the practical perspective required for applied research. Potential exposures for ORNL workers included external radiation, 
plutonium, uranium dust, a variety of other radionuclides, lead, beryllium, and many chemicals associated with research and development laboratories.

The Y $\cdot 12$ plant produced enriched uranium by the electromagnetic separation process and was operated by the Tennessee Eastman Corporation (TEC) from June 1943 through May 1947. TEC produced material with U-235 concentrations of approximateły 88 percent. Besides uranium dust and some external radiation, there was potential for occupational exposures to numerous agents including carbon dust, chlorinated and fluorinated uranium compounds, solvents, lubricants, nitric acjd, hydrogen peroxide, hydrogen fluoride, chlorinating agents, oxidized uranium compounds, and uranyl nitrate.

When management changed from TEC to UCCND in May of 1947, Y-12 plant operations changed in function from uranium enrichment to nuclear materials fabrication. There was also a significant turnover in the workforce with only $3,147(6.7 \%)$ of the wozkforce staying on to work in the new operation. The fabrication work done at Y-12 involved converting U-235 compounds to metal and producing firal products by using casting, rolling, and machining operations. The types of procedures used have remained relatively constant over time. Potential exposures encompassed those from before May 1947 and extended to beryllium, thorium, asbestos, 4,4'-methylene bis(2-choloroaniline) (MOCA), mercury, chtomium, nickel, cadmium, lead, and zinc.

Because of the change in workforce and mission after May 1947, the Y-12 plant is treated as two entities in all descriptions related to the Oak Ridge Institute for Science and Education (ORISE) epidemiologic studies. TEC refers to the Y-12 plant as operated from 
1943 to May 1947, while Y-12 refers to this facility as operated by UCCND from May 1947 to the end of the present study.

The K-25 site, which began full-scale operation in 1945, also produced enriched uranium but used a gaseous diffusion process. The uranium produced there was used initially as feed material for the electromagnetic process at TEC. After the war efficiency of enrichment reached beyond 90 percent, and production at K-25 increased as the tense world political situation made the extraction of U-235 a matter of high priority in the national defense strategy. K-25 workers had potential for exposure to uranium dust, oxidized uranium compounds, uranium hexafluoride, external radjation, fluoride, lead, nickel, cadmium, chromium, perchloroettylene, mercury, lubricants, and laboratory chemicals.

\section{DATA COLLECTION}

\section{Compiling and Checking the Rosters}

In 1965 the Computer Sciences Division of UCCND was asked by the Atomic Energy Commission (AEC) to assemble and computerize employee demographic and monitoring information from hardcopy records for the pilot project of a comprehensive Health and Mortality Study (HMS), which would investigate the effects of long-term exposure to lowlevel radiation among AEC and Manhattan Engineer District contractor employees (Fry et al., 1993; Lushbaugh et al., 1983).

Payroll records, supplemented by medical records, were the main data source for roster construction, although a wide variety of sources was used to assemble and check the integrity of the rosters. The more detailed personnel folders for employees terminated prior 
to 1950 had not been retained at K-25. By the close of FY 1977, an employee roster of nearly 108,000 individuals had been compiled for Oak Ridge facilities. The progress report for FY 1977 noted that the completeness of the roster was verified by cross-checking against the K-25 medical roster, the Y-12 persontnel card index, and the ORNL roster of employees maintained on site by the Health Physics Department, and that extensive effort and cost had been expended in validating the data files and correcting the transcription enors that were found (Mancuso, 1977).

As a current check on the completeness of the rosters, the number of workers employed by Oak Ridge facilities each year beginning with 1944 was obtained independently of the study cohort data by checking annual reports from UCCND (Union Carbide Corporation, 1943-1984). Figure 1 shows the combined number of employees in the study cohort by facility per year versus the number obtained from the corporate reports. It is clear that there is very close agreement between the number of empioyees listed annually after 1947. There are discrepancies from 1944 through 1947 because no corporate reports could be obtained on personnel figures from TEC, and UCCND did not take over management of ORNL until March 1948. However, there is no indication that the study cohort is missing members of the workforce from the Oak Ridge facilities. 


\section{COMPARISON OF ANNUAL EMPLOYMENT FIGURES}

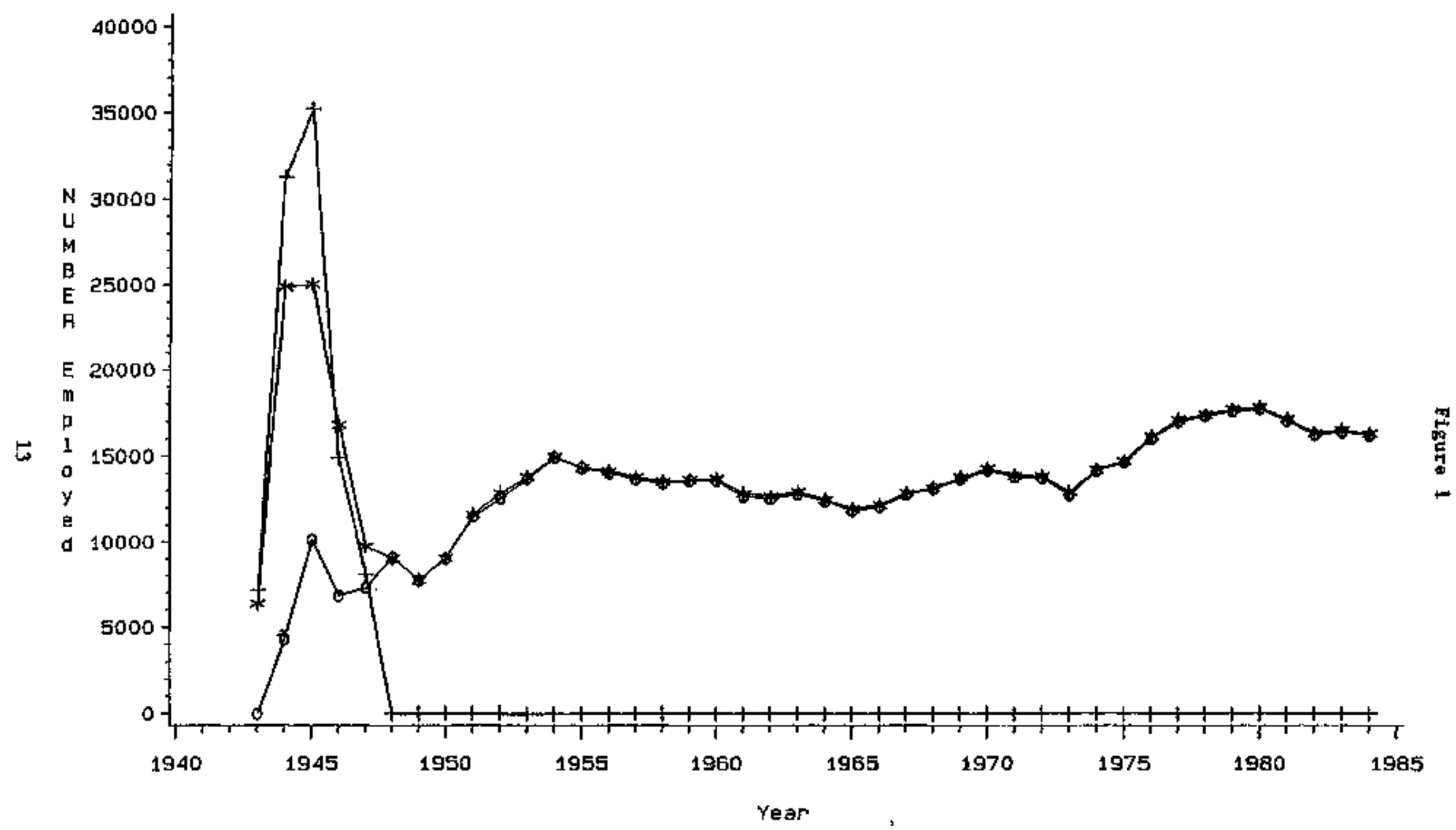

$\rightarrow$ Union Carbide Reports

**** Study cohort for ORNL,Y-12/UCC AND K-25 COMBINED

++ Study cohort for TEC 


\section{Data_Management at ORISE}

At the start of FY 1978 (October 1), data from the Oak Ridge facilities were transferred on a series of magnetic tapes from the original contractor (University of Pittsburgh) to Oak Ridge Associated Universities, which now operates ORISE. The data from these tapes were developed into an integrated database (IDB) at ORISE. The original magnetic tapes contained separate source data files for demographic, work history, and occupational monitoring records (Denton and Fore, 1979). These fles provided attributes for the IDB, including social security number (SSN), name, gender, race, birth date, paycodes, dates for entering and terminating employment and for transferring to another facility, information such as Social Security Administration (SSA) death notices and indicators of various chemical exposukes, as well as personal internal and external radiation monitoring data. Since the original transfer of data from the Oak Ridge facilities, ORISE has regularly recejved machine readable updates, and error detection and corrections have been performed on a continuing basis as described in Gissel et al. (1982). The results of a major audit of the database performed in 1984 showed that the error rate for the previous five years was 0.8 percent for all entries in 15 of the major files of the IDB (Epi-Logs, 1984). Because the entire set of medical records and occupational history records for TEC are stored in a vault at ORISE, extensive data verification has been done for all TEC workers.

A unique ID number was assigned sequentially as data for new employees were added to the IDB. Because information for any individual is contained in a series of tables in the IDB, all records belonging to each worker can be accessed by this common ID number. In addition, the monitoring data for a worker are assigned the same ID through 
a linking algorithm that uses information in all files including SSN, name, dates of employment, and badge numbers to verify that the monitoring data belong to the same individual. For external monitoring data, of the 694,066 ORNL (1943-1985) personnel monitoring records, 25,464 were not usable for ORNL employees; however, at most 552 of the unusable records could have belonged to ORNL employees since the remainder were linked to visitors, consultants, and employees on loan from other nuclear facilities. For the 491,546 Y-12 records (1948-1984), 87 wete unlinkable and an additional 1,127 were identified as belonging to visitors. From K-25 there were 151,134 personnel monitoring records (1945-1985); there were 12 unlinkable and one linked to a visitor (X-10, Y-12, and K-25 Exposure Inventories).

The database at ORISE on which the study is based is dynamic in the sense that any apparent data discrepancies that are discovered are investigated by accessing original hardcopy source documents; when possible, incorrect values are replaced by correct ones. A database table is maintained to document all corrections that have been made. Certain apparent discrepancies were detected when the data were received on tape from the facilities, and others were identified when specific cohorts were chosen to be studied and analyzed (Payne et al., 1991). Once an analysis file has been completed, the values it contains are frozen; they remain unchanged even if errors for study cohort members are subsequently corrected on the database. 


\section{Checks on Data Entry}

At the Oak Ridge nuclear facilities individual monitoring records are presently contained in plant-specific computer files, which have been compiled by a number of techniques. Much of the early data was transferred from hardcopy to keypunch cards, which were read into computer tapes. A double entry technique was generally used as a continuing check on precision. Data entry progressed with technology with recent monitoring records being entered using equipment that can produce computer files directly on tape or disk. Quality assurance programs have been maintained by the plants to insure that data were assigned to the correct individuals and dates. In addition, radiation safety personnel made spot checks near the time the data were first generated to assure that information was entered correctly into the computer system.

\section{Vital Status Data}

In order to successfully complete this study, an adequate and valid vital status follow-up of the study population was essential. The vital status follow-up included three separate functions. The first step was to investigate the vital status of each member of the study cohort. The next task was to retrieve death certificates for individuals identified as deceased and verify that each certifficate matched the corresponding cohort member. Finally, all verified death certificates had to be classified by the cause of death according to the Eighth Revision of the International Classification of Diseases, Adapted for Use in the United States (U.S. Department of Health, Education, and Welfare, 1968). This study population, as part of the HMS, was included in routine vital status updates every two to 
three years for all active and former employees on the rosters of each facility. For this study the SSA was the primary agency employed for ascertainment of vital status. Other sources of vital status information were states' departments of motor vehicles, the Health Care Finance Agency, the offices of personnel management (both active and retired employee branches), and the benefits plans offices at the facilities. Death certiffates were retrieved from either the facility of employment or the state of death. Each death certificate retrieved was classified for the anderlying catuse of death; if a cancer was not the underlying cause of death, then at most one malignant disease classification was included if mentioned. Death certificates were classified by nosologists who were trained and certified by the National Center for Health Statistics (NCHS), and many certificates were classified by two different nosologists as a check on accuracy. Any discrepancies identified were resolved by discussion or by sending the certificate in question to the NCHS for coding.

\section{CREATION OF ANALYSIS FILES}

Analysis files were produced using data from the IDB and the computerized radiation monitoring files at ORISE. These analysis files, along with their documentation, will be available through the Comprehensive Epidemiologic Data Resource (CEDR) of the DOE. The first analysis file contained the demographic and work history data for the 118,588 workers who had been hired at an Oak Ridge facility by December 31,1982 . Of these workers 12,568 were eliminated from the cohort, including 11,002 employed for less than 30 days and 1,566 having data which contained critical errors that made them unsuitable for 
analysis. Table 1 gives a breakdown of the workers eliminated from the study; some workers had multiple errors and are in more than one category.

Radiation monitoring data analysis files spanning the period from plant opening year through 1984 were created for ORNL, Y-12, and K-25. A corresponding file could not be created for TEC because personal monitoring data are not available from that facility. A worker employed at more than one facility during a given year would have an entry in each appropriate anałysis file. For each year these anatysis files contain a code to indicate whether a worker was employed, and also, for each year employed, an indicator variable for internal exposure, and an external radiation dose. The annual external doses were obtained from readings taken at the plants and transferred on tape to ORISE. These computerized data were assessed by health physics personnel at the University of North Carolina at Chapel Hill and ORISE, who developed algorithms for accumulating all film badge or thermoluminescent dosimeter (TLD) readings obtained throughout the year. Two additional analysis files are being praduced and will contain adjusted annual external doses for ORNL and Y-12. These adjustments involve supplying an estimate of external dose for years in which readings were not recorded during years when the monitoring policy was to monitor all workers. Also, for ORNL, doses from 1944 through 1956 will be adjusted upward; for Y-12, nonmonitored years before 1961 will be replaced by an estirnated dose. Details on these adjustment procedures will appear in a supplement to this report. 


\begin{tabular}{|c|c|}
\hline Reason & $\begin{array}{c}\text { Number of } \\
\text { Workers }\end{array}$ \\
\hline Employed $<30$ days & 11,002 \\
\hline Unknown race code & 1,677 \\
\hline Age at first hire $\leq 15$ or $\geq 70$ years & 231 \\
\hline Status not $A, D$, or $U^{*}$ & 159 \\
\hline Missing birth date & 120 \\
\hline Hire date before birth tate & 70 \\
\hline Missing hire date & 64 \\
\hline Hire date before startup ${ }^{* *}$ & 22 \\
\hline Missing last term date & 16 \\
\hline Overlapping employment dates & 11 \\
\hline Unknown gender & 14 \\
\hline \multicolumn{2}{|l|}{$\begin{array}{l}\text { "At Alive; D: Deceased; U: Unknown } \\
\text { "Y-12 hire < 05/04/1947 } \\
\text { TEC hire < 01/01/1943 } \\
\text { K-25 hire < 06/01/1943 } \\
\text { X-10 hire < 01/01/1943 }\end{array}$} \\
\hline
\end{tabular}




\section{VERIFICATION OF DATA IN ANALYSIS FILES}

To verify that data in the analysis files were an accurate representation of data in plant records, a stratified random sample was taken of 500 workers in the same race/gender proportions as the study cohort. Their data were verified by comparing values in analysis Gles to archived hardcopy and other source records at the facilities. Demographic and work history data were checked for all 500 in the sample. Radiation monitoring data were also retrieved for 210 workers who had ever been employed at ORNL or Y-12, including data for years employed at K-25. Personnel at ORNL used hardcopy records for monitoring data that still exist there to produce external dose histories and create an internal indicator of "exposed" or "not exposed" for each year of employment. The definition of internal exposure chosen for the study differed somewhat from the criteria applied by ORNL personnel; this resulted in some instances of assignment to the "exposed" category in the study but "not exposed" by ORNL personnel. Y-12 and K-25 personnel supplied external and internal monitoring data based on their current computer records; the results for internal monitoring were given for each year as the average percent of Radiation Protection Standard (RPS). When the sum of the average percents of RPS for urinalysis and in vivo counting was greater than one percent, the worker was classified as "exposed" for that year for purposes of comparison. Table 2 summarizes the results of this data verification for demographic and internal monitoring data. Figure 2 shows a comparison of the total cumulative external dose from all facilities as recorded in the analysis files and as retrieved from plant records. Results of this random sample data verification lend credibility to the precision of the data in the analysis files. 


\begin{tabular}{|c|c|c|}
\hline \multicolumn{3}{|c|}{$\begin{array}{l}\text { TABLE } 2 \\
\text { Results of Data Verification from Random Sample }\end{array}$} \\
\hline Attribute & $\begin{array}{c}\text { Number of } \\
\text { Workers }\end{array}$ & $\begin{array}{l}\text { Number of } \\
\text { Exact Matches }\end{array}$ \\
\hline Gender & 500 & 500 \\
\hline Race & 500 & $500^{a}$ \\
\hline Paycode & 500 & $499^{6}$ \\
\hline Birthdate & 500 & $495^{c}$ \\
\hline Hire/Term Dates & 500 & 483 \\
\hline $\begin{array}{l}\text { Final Cumulative Internal Exposure } \\
\text { Category (using "never monitored", } \\
\text { "monitored at least once but not } \\
\text { exposed", and "monitored and } \\
\text { exposed at least once") }\end{array}$ & $210^{d}$ & $194^{e}$ \\
\hline $\begin{array}{l}\text { Final Cumulative Internal Exposure } \\
\text { Category (using "never monitored } \\
\text { after } 1950^{\circ,} \text { "employed after } 1950 \\
\text { but never monitored", and } \\
\text { "monitored and exposed at least } \\
\text { once") }\end{array}$ & $210^{\mathrm{d}}$ & 205 \\
\hline \multicolumn{3}{|c|}{$\begin{array}{l}\text { ane of these workers had two race codes available on different hardcopy } \\
\text { records, and one corresponded to the race code in analysis file. }\end{array}$} \\
\hline \multicolumn{3}{|c|}{ bone paycode previously unknown was discovered. } \\
\hline \multicolumn{3}{|c|}{$\begin{array}{l}\text { Three of these workers had multiple birthdates on different hardcopy } \\
\text { records with one corresponding to birthdate in analysis file. }\end{array}$} \\
\hline \multicolumn{3}{|c|}{$\begin{array}{l}\text { 'Total number of individuals from the } 500 \text { who were ever employed by } \\
\text { ORNL, Y-12, or both. }\end{array}$} \\
\hline \multicolumn{3}{|c|}{$\begin{array}{l}\text { For } 11 \text { of the } 16 \text { discrepancies the worker was categorized as exposed } \\
\text { from analysis file data but as not exposed from the verification data. }\end{array}$} \\
\hline
\end{tabular}




\section{COMPARISON OF CUMULATIVE EXTERNAL DOSE THROUGH 1984 ANALYSIS FILE TOTALS VS. FACILITY RECORDS \\ (For 210 Workers From a Random Sample of the Study Cohort)*}

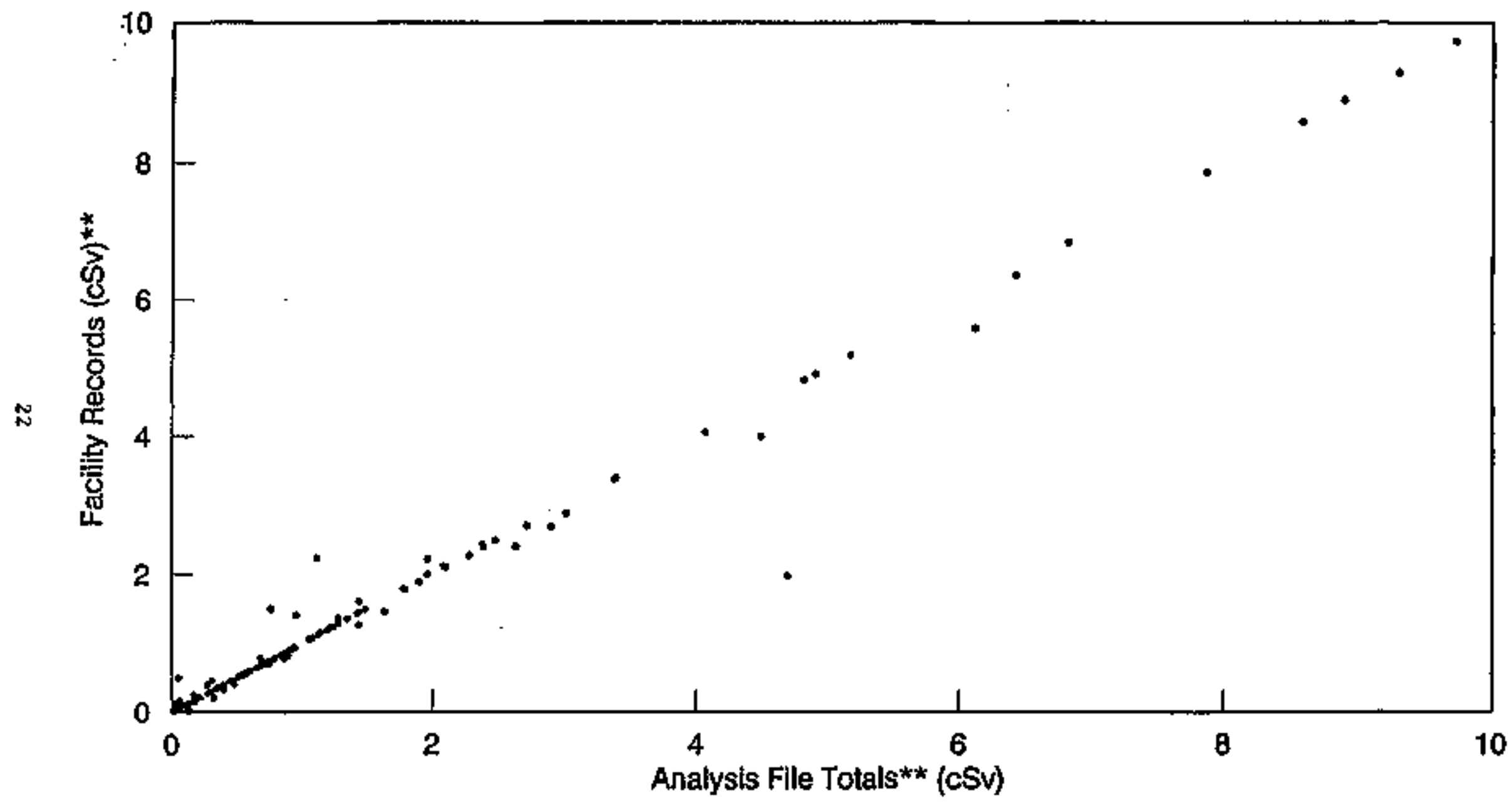

*54 workers have no occupational exposure recorded In analysis files and in facility records

** Omitting four observations with $>10 \mathrm{cSv}$ for both totals 


\section{DESCRIPTION OF DATA FOR THE STUDY POPULATION}

\section{Demographic Characteristics of the Study Cohort}

The cohort for this study consists of 106,020 workers hired by December 31,1982 , employed for at least 30 days, and having data free from critical errors. Table 3 provides descriptive demographic information for the study cohort by race and gender. White males comprise the largest segment of the population $(68,666)$ and the highest percentage of working years $(79 \%)$. The white males and white females have the largest total person-years of foltow-up with $1,824,040$ and 833,094 years, respectively. The reason that the white females comprise only 15 percent of the total person-years of employment but 30 percent of follow-up while the white males comprise 79 percent of the person-years of employment but only 65 percent of follow-up, is that 66 percent of the white females and only 44 percent of the white males were employed only during WWII. This early entry of females into follow-up can also be seen wher looking at the facility of employment for each group. Nearty 50 percent of the white females and the nonwhite females were employed only by TEC while, in contrast, less than 25 percent of the white males and the nonwhite males were employed only at TEC.

The proportion of each race/gender group with unknown vital status is atso shown in Table 3. Only 11.5 percent of the study cohort had an "unknown" vital status as of December 31, 1984; death certificates were retrieved, verified, and classified for 97.9 percent of those known to have died. Only six percent of white males had an "unknown" vital status at the end of the study while this percent was much higher for the other race/gender groups. There may be an underascertainment of deaths for females as vital status is "unknown" for 
over 20 percent of females in both race groups. Absence of vital status data for females may have been due in part to name changes. The cause of death was determined (t.e., a death certificate was located) for over 90 percent of the known deaths in all race/gender groups.

The Appendix of this report contains a series of tables that present the demographic characteristics of the suboohort used for facility comparison analyses and the subcohort used for the dose-response analyses. 
Table 3

Demographic Data Information on Study Cobort

\begin{tabular}{|c|c|c|c|c|}
\hline & \multicolumn{2}{|c|}{ Males } & \multicolumn{2}{|c|}{ Femtales } \\
\hline & White & Nonwhite & White & Nonwhite \\
\hline Number of workers ( $\%$ of tolal number) & $68,666(65)$ & $4,238(4)$ & 29,805 (28) & $3,311(3)$ \\
\hline \multicolumn{5}{|l|}{$\begin{array}{l}\text { Number of workers by facitity } \\
\text { (\% of number in raceigender group) }\end{array}$} \\
\hline ORNL onty & $11,349(17)$ & $1,021(24)$ & $3,902(13)$ & $464(14)$ \\
\hline TEC oniy & $16,503(24)$ & $942(22)$ & $14,483(49)$ & $1,627(49)$ \\
\hline Y-12 only & $8,591(12)$ & $629(15)$ & $1,465(5)$ & $283(9)$ \\
\hline $\mathrm{x}-25$ only & $21,279(31)$ & $945(22)$ & $6,870(23)$ & $533(16)$ \\
\hline MUL (worked in multiple factlities) & $10,944(16)$ & $701(17)$ & $3,085(10)$ & $404(12)$ \\
\hline $\begin{array}{l}\text { Number employed only during WWI } \\
\text { (\% of number in race/gender group) }\end{array}$ & $31,337(46)$ & $1,750(41)$ & $20,164(68)$ & $2,065(62)$ \\
\hline $\begin{array}{l}\text { Total person-years of follow+up } \\
\text { (\% of total person-years) }\end{array}$ & $\mathrm{L}, \$ 24,000(65)$ & $82,700(3)$ & $833,100(30)$ & $70,400(2)$ \\
\hline $\begin{array}{l}\text { Total person-years of employment } \\
\text { (\% of total person-years) }\end{array}$ & $462,824(79)$ & 23,055 (4) & $91,757(15)$ & $9,596(2)$ \\
\hline \multicolumn{5}{|l|}{$\begin{array}{l}\text { Total person-years of employment by facility } \\
\text { (\% of total in race/gender group) }\end{array}$} \\
\hline ORNL & $130,780(28)$ & $8,163(35)$ & $27,747(30)$ & $2,708(28)$ \\
\hline Y.12 & $157,994(34)$ & $7,549(33)$ & $19,095(21)$ & $2,688(28)$ \\
\hline $\mathrm{K}-25$ & $148,020(32)$ & $6,394(28)$ & $28,365(31)$ & $2,727(29)$ \\
\hline TEC & $26,030(6)$ & $849(4)$ & $16,550(18)$ & $1,472(15)$ \\
\hline \multicolumn{5}{|c|}{ Vital status (\% of number în race/gender group) } \\
\hline alive & $41,748(61)$ & $2,499(59)$ & $19,648(66)$ & $1,944(59)$ \\
\hline dead & $22,724(33)$ & $1,121(26)$ & $3.595(12)$ & $542(16)$ \\
\hline unknown & $4,194(6)$ & $618(15)$ & $6,562(22)$ & $825(25)$ \\
\hline $\begin{array}{l}\text { Number with death certificate retrieved } \\
\text { (\% of deceased in race/gender group) }\end{array}$ & $22,283(98)$ & $1,072(96)$ & 3,452 (96) & $510(94)$ \\
\hline
\end{tabular}




\section{Badiation Monitoring Data}

Monitoring Policies at the Facilities

Historically, the main purpose of the radiation monitoring programs has been to assure that each worker's exposure to radiation was kept below the current annual prescribed occupational exposure linit, the current U.S. dose limit being 5 cSv. Because of this aim, data collection in the early years was very limited for workers who were considered to have low potential for exposure. Also, limited information is available concerning the rationale used to decide which workers to monitor, implementation of these decisions, and the methods used for assessing reliability, variability, and lower limits of detection. At each facility the radiation safety personnel were responsible for the monitoring program, making the programs essentially independent of each other. Present policy mandates laboratory intercomparison and requires monitoring at much lower levels of potential exposure as well as extensive documentation of quałity assurance records and results. Consequently, dose evaluation of more recent data and inter-płant comparability should be significantly iraproved over that for earlier time periods.

Figure 3 summarizes both the internal and external radiation monitoring policies in place at the facilities during their periods of operation. A change in policy was generally phased in over the course of several months. Once monitoring programs were begun, internal monitoring data were available for those workers who were judged to have exposure potential. Because internal monitoring programs were begun in 1951 by ORNL, in 1950 by $Y+12$, and in 1948 by K-2S, the definition of "not monitored" varies by plant and by year. By the early 1950 s a worker who was not monitored for internal exposure was judged to 


\section{PERSONAL MONITORING POLICIES FOR OAK RIDGE WORKERS BY PLANT, 1943-1984}

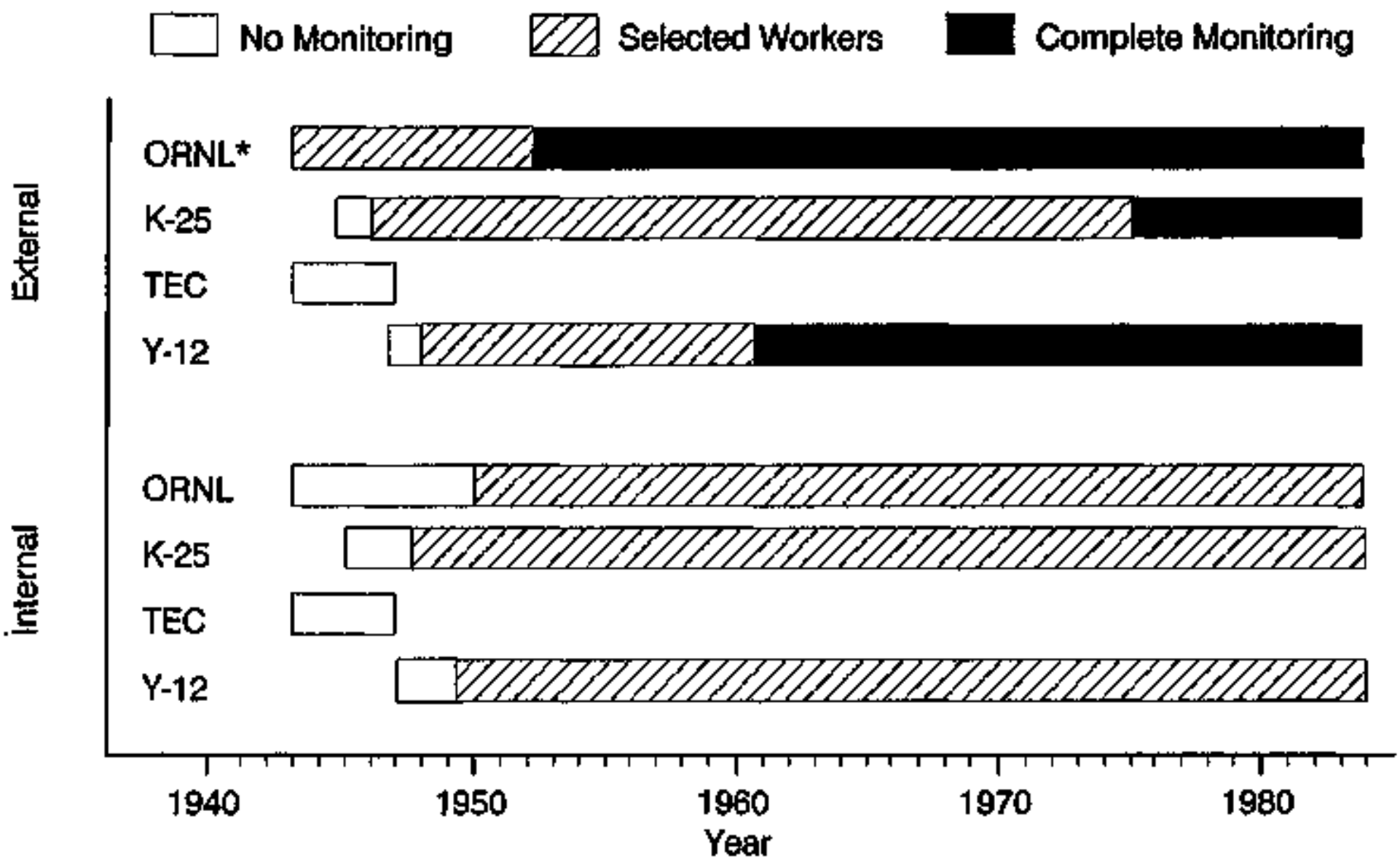

*Seo text for additional information on monitoring data prior to 1952 
have low potential for exposure. Because of policies in effect, external monitoring data are available for most workers from Y-12 only since 1961 and from K-25 not until 1975. ORNL began monitoring for external radiation in 1943 , which was earlier than the other facilities. Before November 1951 only those workers entering areas of potential external radiation exposure were monitored for external dose. In 1947 all workers entering a radiation area more than three times a week were assigned permanent film badges, but by 1949 permanent film badges were issued to all workers entering these restricted areas at least once a week. In November of 1951 all workers entering the main X-10 area were required to have a film badge, and by September of 1953 the film badge and security badge needed for entry were combined into one (Hart, 1966; West, 1992A). Over 95 percent of the computerized annual dose records from 1947 through 1951 for ORNL workers had an occupational dose recorded, although many of the recorded doses were zero. A random sample of hardcopy records, which contained the weekly film badge readings that were summed to obtain the annual doses, revealed that a dose of zero was assigned in the computerized flle when a worker had no recorded monitoring results on the hardcopy record.

External Radiation Dose

External doses for Oak Ridge workers were obtained from personnel integrating dosimeters, most frequently the photographic film dosimeter (film badge) prior to the late 1970s and the TLD since then. In a film badge the darkening of the film after processing can be related to the magnitude of the radiation exposure. For early tilm badges the minimum detectable dose was approximately $0.025 \mathrm{cSv} \pm 0.010 \mathrm{cSv}$ (Maienschein, 1992). The sensitivity of film badges in later years was improved over that of earlier years. An 
ORNL report from 1952 stated that the practical useful range for sensitive film badges was 0.03-100 $\mathrm{eSv}$ (Craft, 1952). Calibration curves that the lower detection limit could reach 0.01 cSv by the early 1960s. A disadvantage of the film badge was that the response of the film to photons was energy dependent, and an over-estimation of doses could have occurred because of the over-response of film to photons in the 60 to $90 \mathrm{keV}$ range. An estimate of overall error in film badge readings under ideal conditions is $\pm 10-40$ percent for photon monitoring, $\pm 21-41$ percent for beta monitoring, and $\pm 11->100$ percent for monitoring thermal neutron exposure (Chabot, 1978). Thermal heating of material within a TLD causes an emission of light proportional to the radiation exposure that was received. TLDs are relatively independent of photon energy and are able to measure $\mathrm{X}$ and gamma ray doses as low as $0.01 \mathrm{cSv}$ with an estimated accuracy of \pm 20 percent for mixed gamma exposures and \pm 40 percent for beta exposures (Chabot, 1978), Pocket ionization chambers (pocket meters) were also used in the early days of plant operations, particularly to obtain interim values between fillm badge readings, and continue to be used even today when high exposure potential is suspected (Parrish, 1982). Pocket meters can measure integrated X rays or gamma rays, but only higher energy beta particles can be detected. Figure 4 summarizes by plant and year the types of dosimeters generally in use and the frequency at which they were reat. New devices and changes in frequency of monitoring sometimes were phased in over the course of several months. 


\section{TYPES OF DOSIMETERS AND FREQUENCY OF READINGS FOR MONITORED OAK RIDGE WORKERS BY PLANT, 1943-1984}

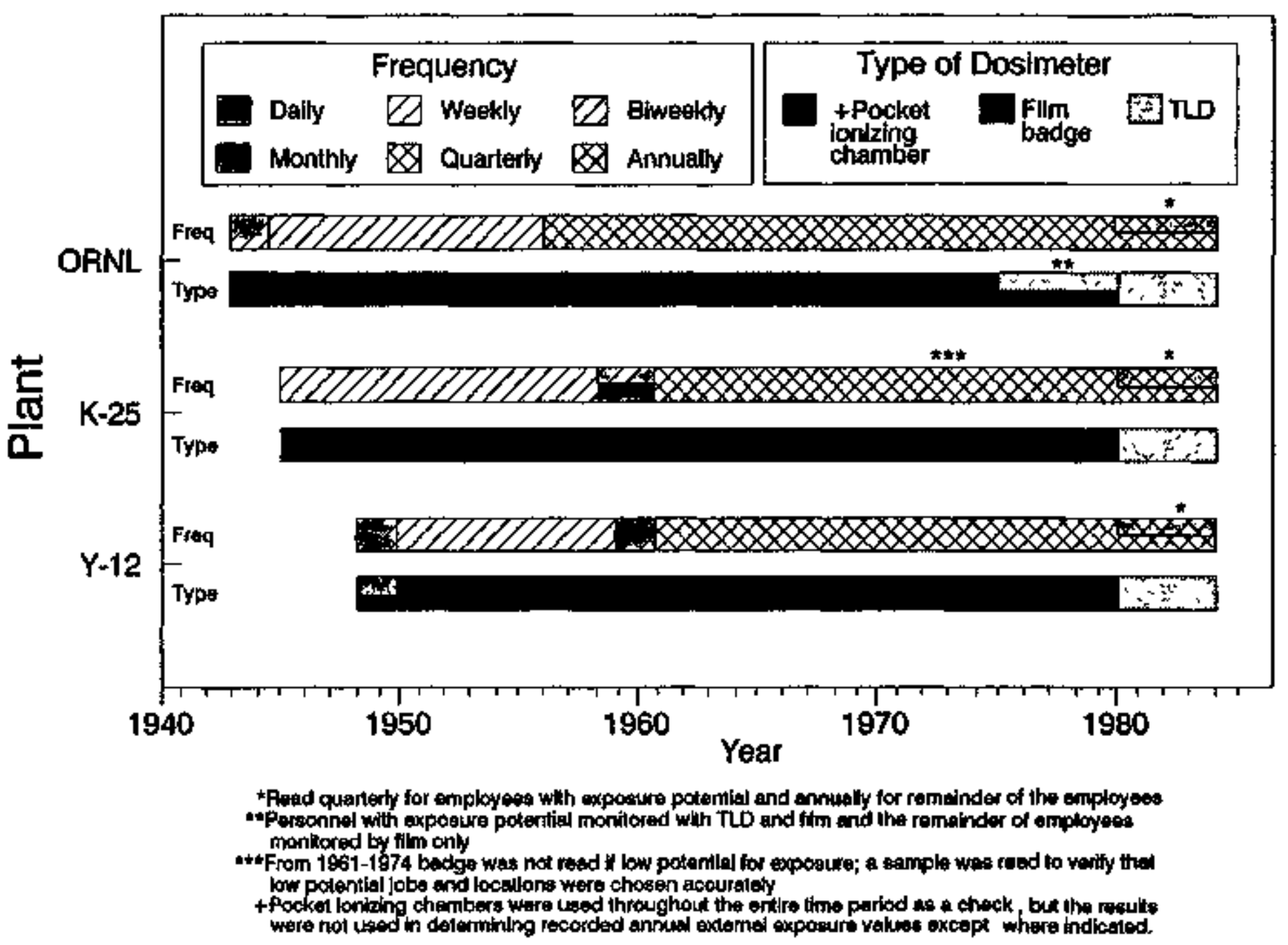


After extensive error checking procedures (Crawford-Brown et al, 1989), annual external doses were calculated by summing all credible gamma and neutron film badge readings taken during the year. Because of the variability in dosimeter types, reading frequencies, and monitoring policies over time and facilities, annual doses obtained from the simple summing of readings during the year may not be comparable at all times, and a recorded dose may not always accurately represent the true amount of a worker's radiation exposure. To compensate for this potential incomparability and possible inaccuracy in recorded doses, particularly in early years, adjusted annual doses are being calculated as the starting point for additional dose-response analyses. Adjusted doses will be discussed further in a supplement to this report.

For the exposure analyses in this study, first cumulative annual doses for each year were obtained by summing annual doses received at ORNL, Y-12, or K-25 from entry into the study through that year, and then workers were placed in categories of increasing cumblative external dose. Because a worker entered follow-up for the dose-response analysis 365 days after first hire at either ORNL or Y-12, the cumulative dose for his first year of follow-up was the sum of his dose for the first year he worked and the first year he entered the study. In addition, if he had previously worked at K-25 and had records of external doses received there, the K-25 total was included in the cumulative external dose for the first year of follow-up. A worker contributed person-years to all dose categories through which he moved to reach his final cumulative dose category. 


\section{Internal Radiation Exposure}

Film badges measure external exposure over a given period of time; monitoring for internal exposure is performed at specific points in time; therefore, the results are estimates of the body or organ buiden at the time of measurement. The primary methods of internal monitoring used were urinalysis and in vivo gamma spectrometry, but fecal analysis was also performed in some instances. The dosimetry associated with analysis of urine for radioisotopes of concern depends on relating the amount of an isotope in a reference volume of urine to the amount contained in the body or in specific organs. The relationship between these two amounts is affected by many variables, such as the radioisotope, time since exposure, the chemical and physical form of the isotope, and biological variation among individuals. The most straightforward estimator of the amount of a radioisotope in the body or its organs is in vivo analysis with gamma spectrometry. Employees were monitored by placing them inside a heavily shielded room, and measuring gamma ray emissions using calibrated spectrometers. Natural radioactivity in the human body and varying amounts of natural background radiation add uncertainties to the measurements obtained. The monitoring programs tested for 36 radioisotopes at ORNL, for seven at K-25, and for five at $\mathrm{Y}-12$. Table 4 lists these isotopes by facility.

In general, workers were monitored only if they worked in locations or administrative groups that were judged by supervisors or radiation safety organizations to have internal exposure potential. Periodically, after about 1950 individuals from the among unmonitored workers were randomly selected and monitored by ORNL and K-25 


\begin{tabular}{|c|c|}
\hline & $\begin{array}{c}\text { Table } 4 \\
\text { Inventory of Radionuclides by Facility }\end{array}$ \\
\hline Facility & Radionuclides \\
\hline ORNL & $\begin{array}{l}\text { Co-60, Cs-137, Cs-134, rare earths, fission products, H-3, } \\
\text { Pa-231, P-33, P-32, Po-210, Pu-238, Pu-239, Pu-241, Ra-226, Ru- } \\
\text { 106, Sr-90, Sr-85, Sr-89, transplutoniums, uraniums, S-35, Pb-210, } \\
\text { Na-24, Zn-65, Tc-99, As-74, Br-82, Fe-59, Mn-54, I-131, Ba-140, } \\
\text { Sn-125, T1-204, Np-239, Ag-110 }\end{array}$ \\
\hline $\mathrm{K}-25$ & U-234, U-235, U-238, Pu-239, Sr-90, Np-237, Tc-99 \\
\hline$Y-12$ & U-234, U-235, U-238, Th-232, Th-228 \\
\hline
\end{tabular}

to confirm that unmonitored workers were indeed unexposed to internal radiation (Gupton, 1981). These checks supported the premise that most persons with exposures of detectable magnitude were being monitored. It was the stated policy at $\mathrm{Y}-12$ to increase monitoring frequency as internal exposure potential increased.

Because of the great differences in potential radiation exposure among tacilities, a common indicator of internal exposure for each individual for each year of employment at ORNL, Y-12, and K-25 was assigned one of three values. These values were "not monitored" when no bioassay samples and no in vivo counts existed for the year; "not exposed $\mathrm{d}^{\text {tt }}$ when an employee's monitoring results were indicative of internal doses of less than $0.1 \mathrm{cSv}$ for the year; and "exposed" when monitoring results indicated a dose of $0.1 \mathrm{cSv}$ or more total from all monitored rađioisotopes. The cutoff of 0.1 cSv was chosen because dose estimates smaller than this could not validly be considered positive results. For ORNL 
and K-25 urine results were used to calculate expected annual doses by comparison with urine excretion indices (E.I.) established by each plant for each monitored isotope to indicate the level of urine excretion rate corresponding to internal dose of $5 \mathrm{cSv} / y$ ear total bady, 30 eSv/year bone, or 15 cSv/year for other organs, based on certain conservative assumptions about solubility of materials and equilibrium conditions. E.Is for fecal analyses were set 10 times higher than urine E.Is for the same isotope. At ORNL in addition to urinalysis results, whole body counting result codes indicating percent permissible organ burden measured were used to estimate annual doses. When the sum of the doses for all monitored isotopes equalled or exceeded $0.1 \mathrm{cSv}$, the person-year was classified as exposed. There was no significant exposure potential for radioisotopes other than uranium and thorium at Y-12. Annual internal doses from uranium, previously calculated from quantitative urinalysis and whole body counting results, as described in Crawford-Brown et al., (1990) and Hazards Assessment Group (1989), were added to estimates of lung doses from thorium burdens and compared to the $0.1 \mathrm{cSv} /$ year cutoff to determine annual interna! exposure category.

Workers at TEC had a high potentjal for internal contamination because of the process performed at the facility. However, personal monitoring data were not availabte from TEC records because no bioassay or whole body counting programs were established when it was in operation. An investigation into the job titles of the 2,837 TËC white male workers who later went on to work at either Y-12 or ORNL revealed that the majority remained in jobs with similar internal exposure potentials, anđ 1,147 (40\%) were classified as internally exposed for at least one year during employment at either Y-12 or ORNL. 
Table 5

Monitoring Data Information on the Study Cohort

\begin{tabular}{|c|c|c|c|c|}
\hline & \multicolumn{2}{|c|}{ Males } & \multicolumn{2}{|c|}{ Females } \\
\hline & White & Nonwhite & White & Nonwhite \\
\hline $\begin{array}{l}\text { Number monitored for external or internal } \\
\text { radtation (\% of race/gender group monitored) }\end{array}$ & $33,0888(48)$ & $2,392(56)$ & $7,809(26)$ & $1,161(35)$ \\
\hline $\begin{array}{l}\text { Number monitored for externil dose } \\
\text { (\% of raceigender group monitored) }\end{array}$ & $31,587(46)$ & $2,354(56)$ & $7,607(25)$ & $1,154(35)$ \\
\hline \multicolumn{5}{|c|}{$\begin{array}{l}\text { Namber of workers by final cumulative external dose } \\
\text { (\% of tumber monitored in race/gender group) }\end{array}$} \\
\hline$<105 v(\%)$ & $24,661(78)$ & $2,109(90)$ & $7,305(96)$ & $1,119(97)$ \\
\hline$\geq 1$ to $<5 \mathrm{cSv}(\%)$ & $5,565(18)$ & $201(8)$ & $272(4)$ & $35(3)$ \\
\hline$\geq \operatorname{sesv}(\%)$ & $1,361(4)$ & $44(2)$ & $30(0)$ & $0(0)$ \\
\hline $\begin{array}{l}\text { Total external dose (cSv) } \\
\text { (\% of total dose) }\end{array}$ & $37,619(93)$ & $1,220(3)$ & $1,537(4)$ & $168(0)$ \\
\hline \multicolumn{5}{|l|}{$\begin{array}{l}\text { Total extermal dose (cSv) by facility } \\
\text { (\% of total dose in race/gender group) }\end{array}$} \\
\hline ORNL & $23,885(64)$ & $789(65)$ & $787(51)$ & $75(45)$ \\
\hline$Y+12$ & $12,537(33)$ & $377(31)$ & $682(45)$ & $80(48)$ \\
\hline $\mathrm{K}-25$ & $1,197(3)$ & $54(4)$ & $68(4)$ & $13(7)$ \\
\hline \multicolumn{5}{|l|}{$\begin{array}{l}\text { Total number of annual doses by facility } \\
\text { (\% of these aunual doses not avatlable) }\end{array}$} \\
\hline ORNL (1943-1984) & 146,229 (3) & $9,287(4)$ & $33,007(6)$ & $3,232(6)$ \\
\hline Y-12 (1948-1960) & $51,854(86)$ & $1,500(97)$ & $7,843(96)$ & $606(98)$ \\
\hline (1961.1984) & $121,069(2)$ & $7,056(4)$ & $14,162(4)$ & $2,475(4)$ \\
\hline K-25 (1943-1974) & $132,838(89)$ & $4,206(96)$ & $1,371(100)$ & $26,078(100)$ \\
\hline$(1975-1984)$ & $43,261(6)$ & $3,603(6)$ & $10,339(5)$ & $2,058(5)$ \\
\hline
\end{tabular}




\section{Monitoring Data Characteristics of the Study Cohort}

Table 5 sumnarizes by race and gender the information avajlable from the radiation monitoring data. Females were less likely than males to be monitored for external radiation dose, which retlects the higher proportion of females who worked only during WWII at the TEC facility. White males received 92.8 percent of the total $40,545 \mathrm{cSv}$ of recorded external dose. Only 3.3 percent of the total external dose was recorded at K-25; no monitoring data were available from TEC.

The relative lack of external dose for all groups except white males, and the limited number of records and the extremely low levels of external radiation recorded at $\mathrm{K}-25$ made it evident that analyses involving exposure data would be more efficient utilizing the 28,770 white males who had ever been employed at either ORNL or Y-12. White males employed only at TEC were excluded from the dose-response analyses because of the low potential for external radjation exposure at TEC, and because no personal radiation monitoring data were available from TEC. Workers employed only at K-25 were not included because $80-95$ percent of the K-25 cohort were lacking any external dose data for any year before 1975 and over 90 percent were lacking readings for the majority of their working years at K-25. During the 1944-47 period when employment at K-25 was at its peak, fewer than 500 individuals were monitored; the remaining workers were judged to be at low risk for external radiation exposure. In addition, 88 percent of the annual doses that do exist for K-25 workers are $0 \mathrm{cSy}$. However, in order to make a worker's cumulative dose more accurate, all doses available from K-25 were included for ORNL and Y-12 workers who had also been employed at $\mathrm{K} \cdot 25$. 


\section{TOTAL ANNUAL EXTERNAL DOSE BY FACILITY}

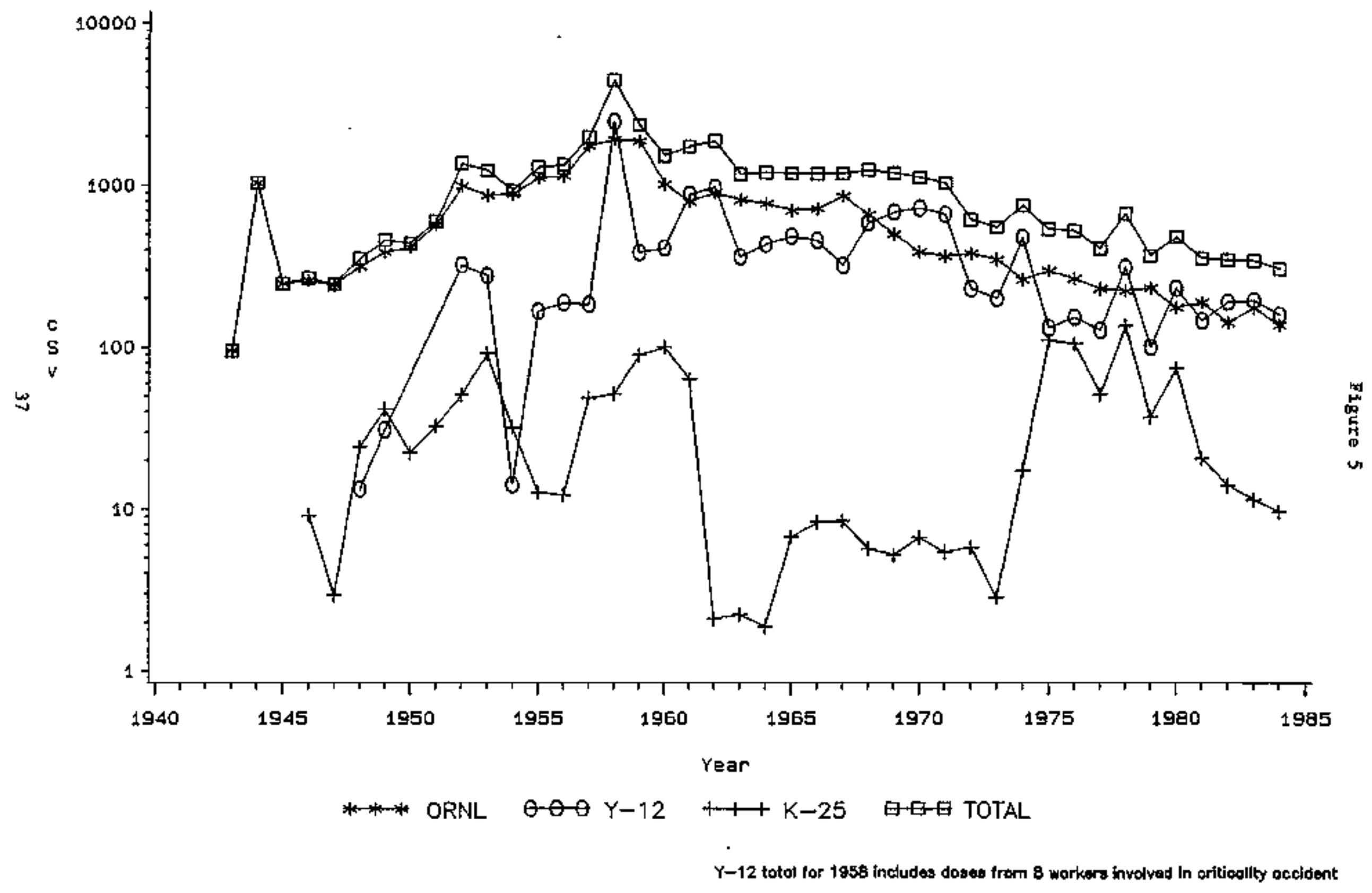


Figure 5 shows the total annual external dose by facility. There is an increasing trend in external doses at ORNL until the late 1950 s and a steady decrease afterwards, while at Y.12 there is greater variability in the total recorded annual external dose. The X-12 peak in 1958 is due to a criticality accident involving eight workers and does not represent a general increase in external dose. External dose recorded at $\mathrm{K}-25$ is generally well below the amounts received at ORNL and Y-12. Figures 6 and 7 depict the percentages of workers monitored annualy for external dose and internal radiation exposure by facility. These percentages reflect the montoring palicies in effect each year by facility. With very few exceptions, fewer than 40 percent of the workers at any plant were monitored for internal exposure in any given year. Intenal monitoring record̈s from $\mathrm{K}-25$ were inctuded as a part of the internal exposure data that determined internal exposure classifications for workers in the subcohort of workers used in the dose-response analysis. This subcohort was comprised of white males who had ever been hired at ORNL or Y+12. 


\section{PERCENT MONITORED FOR EXTERNAL DOSE BY FACILITY}

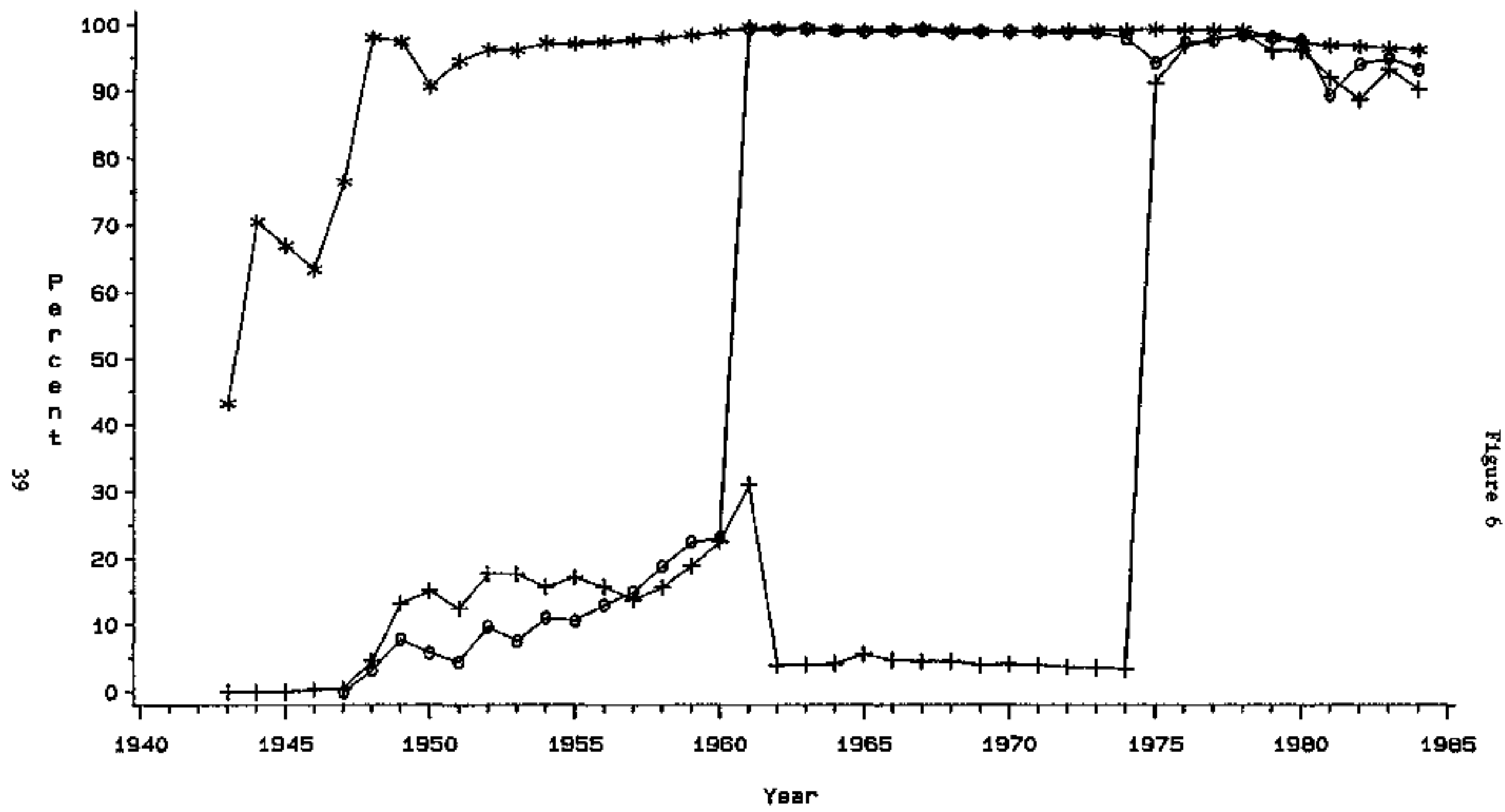

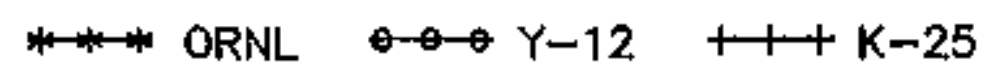

For ORNL from 1947 to 1951 there are some annual doses of 0 in the raw data fils that wore assigned to workere who never entered reatricted areas and so were not actually monitored. Eeginning ln Novernber 1951 al ORHL. employees were monitored, regardless of access to radiation areos. 


\section{PERCENT MONITORED FOR INTERNAL EXPOSURE BY FACILITY}

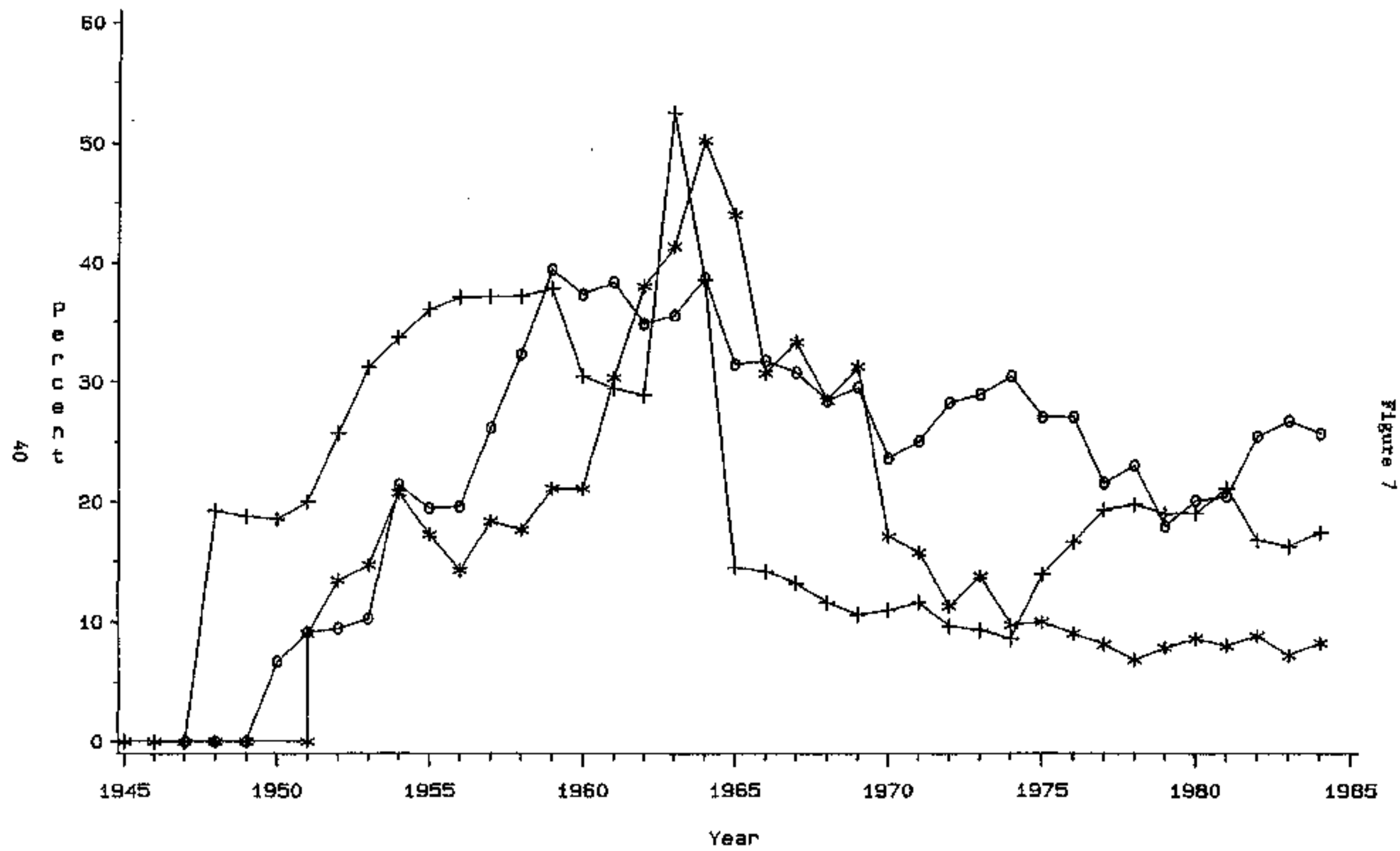

\#\# ORNL $-0-0$ Y12 +世 K25 


\section{DISCUSSION}

Results of validation checks indicate that the study cohort included the vast majority of workers hired at Oak Ridge nuclear facilities before January 1, 1983. Because the study period extended through December 31, 1984, there was a long period of follow-up for examining mortality experience of workers hired during early yeers of plant operation when radiation protection standards were less strict. Data checks and corrections made throughout the process of computerizing and linking data and setting up the ORISE database have resulted in demographic, work history, and radiation monitoring data having a high degree of precision. The quality of the data was confirmed by the results of a random sample data verification, which involved checking against original hardcopy and other source records currently on file in the Oak Ridge nuclear facilities. Vital status is likely underascertained for females. Internal monitoring data were complete enough to classify each year of employment as "exposed", "not exposed", or "not monitored", although "not monitored" had a different meaning before internal monitoring programs were established (1951) than afterwards. During early years of plant operation external monitoring data may not be complete for those workers considered to be at low tisk for radiation exposure. However, the external doses upon which the study is based have been compiled with a high level of precision from the original monitoring records. Of the total of $40,550 \mathrm{cSv}$ external dose recorded for the study cohort, 63 percent was recorded by ORNL, 34 percent by Y-12, three percent by $\mathrm{K}-25$, and none by TEC, which was in operation only duting WWII when monitoring programs were just beginning. In addition,

93 percent of the recorded external dose was assigned to white males, and 91 percent to 
white males who had ever been employed at ORNL or Y-12. As a result of the investigation into monitoring policies in effect at the various facilities over the 42 years covered by the study, it was determined that doses recorded at ORNL before 1957 and unmonitored years at Y-12 before 1961 may have resulted in an underestimation of external radiation doses to workers at these facilities. Therefore, estimates are being made for unrecorded doses and adjustments are being made to doses from the years indicated to produce a second set of external dose analysis files. Details on these adjusted doses will appear in a supplement to this report. Dose-response analyses will be conducted using cumulative external doses based first on actual recorded values and then on the adjusted doses for ORNL and Y-12. 


\section{REFERENCES}

Carpenter, A. V., Flanders, W. D., Frome, E. L., Crawford-Brown, D. J., and Fry, S. A. Central nervous system cancers and radiation exposure: A case-control study among workers at two nuclear facilities

J. Occup. Med. 29(7), pp. 601-604, July 1987

Chabot, G. E., Jimenez, M. A., and Skable, K. W.

Personnel Dosimetry in the USA

Health Physics 34:311-321, April 1978

Checkoway, H., Mathew, R. M., Wotf, S. H., Shy, C. M., Muller, S. M., Beck, J., Watson, J. E., Wray, M., and Fry, S. A.

Mortality among workers at the Oak Ridge National Laboratory

In: Epidemiology Applied in Health Physics, CONF-830101, 1983

Checkoway, H., Mathew, R. M., Shy, C. M., Watson, J. E., Tankersley, W. G., Wolf, S. H., Smith, J. C., and Fry, S. A.

Radiation, work experience and cause specific mortality among workers at an energy research laboratory

Brit. J. Indus. Med. 42:525-533, 1985

Checkoway, H., Pearce, N. E., Crawford-Brown, D. J., and Cragle, D. L.

Radiation doses and cause-specific mortality among workers at a nuclear materials fabrication plant

Am. J. Epid. 127(2):255-266, 1988

Cookfair, D. L., Beck, W. L, Shy, C., et al.

Lung cancer among workers at a uranium processing plant

Presented at the 16th Midyear Topical Meeting of the Health Physics Society,

Albuquerque, NM, January 1983

Craft, H. R., Ledbetter, J. L., and Hart, J. C.

Personnel Monitoring Operating Techniques

Technical Report ORNL-1411, October 1, 1952

Cragle, D. L., Hollis, D. R., Qualters, J. R., Tankersley, W. G., and Fry, S. A. A mortality study of men exposed to elemental mercury

J. Occup. Med. 26, 817821,1984 A 
Cragle, D. L, Hollis, D. R., Shy, C. M., and Newport, T. H.

A retrospective cohort mortality study among workers occupationally exposed to metalic nickel powder at the Oak Ridge Gaseous Diffusion Plant

In: Nickel in the Human Environment (F. W. Sunderman et al., Eds.), pp. 57-63

Scientific Pubtication No. 53, International Agency for Research on Cancers, Lyon, 1984B

Cragle, D. L, Welks, S. M., and Tankersley, W. G.

An oceupational morbidity study of a population potentially exposed to epoxy resins, hardeners, and solvents

Journal of Applied Occupational and Environmental Hygiene

$7(12): 8260834,1992$

Crawford-Brown, D. J., Watson, J. E., Strom, D. J., and Tankersley, W. G.

Procedures for assessing occupational radiation monitoring data for use in epidemiologic studies

Technical Report A-127

Oak Ridge Associated Universities, January 1989

Denton, L. F., and Fore, H. L.

Review of current status of the DOE Health and Mortality Study (HMS) data at UCC-ND/CSD

Technical Report, October 11, 1979

Epi-Logs, Newsletter for the Center for Epidemiologic Research of Oak Ridge Associated Universities, July-August 1984, pp, 3-4

Frome, E. L., Cragle, D. L, and McLain, R. W.

Poisson regression analysis of the mortality among a cohort of WWII nuclear industry workers

Radiation Research, 123, 138-152, 1990

Fry, S. A., Cragle, D. L., Crawford-Brown, D. J., Dupree, E. A., Frome, E. L., Gilbert, E. S. Petersen, G. R., Shy, C. M., Tankersley, W. G., Voelz, G. L., Wallace, P. W., Watkins, J. P., Watson, Jr., J. E., and Wiggs, L. D.

Studies of health and mortality among contractor employees at United States Department of Energy facilities

American Chemical Society, in press (1993)

Gissel, K. C., Hansard, M. S., and Wray, M. I.

HMS error detection, reporting, and resolution system

Statistical Methods and the Improvement of Data Quality

ISBN 0-12-765480-1, pp 321-332, 1983 
Gupton, E. D.

Methods and Procedutes for Internel Radiation Dosimetry at ORNL

ORNL Technical Report ORNL/TM-7923, August, 1981

Hacker, B. C.

The Dragon's Tail, Radiation Safety in the Mankattan Project, 1942-1946

University of California Press, Berkeley, 1987

Hart, J. C.

A progress report dealing with the derivation of dose data from ORNL personnel exposure records applicable to the Mancuso study

ORNL Technical Report ORNL/M-2614 (formerly, ORNL CFM 66-1-84), Oak Ridge, TN

January 14, 1966

Hazards Assessment Group

Oak Ridge Institute for Science and Education

Y12INTEXT Radiation Dosimetry File

Internal Memorandurn, July 20, 1989

Hewlett, R. J. and Duncan, F.

A history of the United States Atomic Energy Commission

Vol. II, Atomic Shield, 1947/1952

U.S. Atomic Energy Commission, 1972

K-25 Exposure Inventory

Center for Epidemiologic Research, Oak Ridge Institute for Science and Education.

Lushbaugh, C. C., Fry, S. A, Shy, C. M., and Frome, E. L.

The DOE Health and Mortality Study at Oak Ridge

In: Proceedings of the Sixteenth Midyear Topical Symposium

U.S. Department of Energy Report CONF-830101, pp. 105-114

Albuquerque, New Mexico, 1983

Maienschein, F. C. and Peelle, R. W.

Radiation dose estimation and health risk

JAMA, Vol. 267, No. 7, pp. 929.930, (1992)

Mancuso, T. F.

Study of the lifetime health and mortality experience of employees of ERDA contractors Final Report 13, July 31, 1977

Technical Report C00-3428-8, Department of Industrial Environmental Health Sciences

University of Pittsburgh, Pittsburgh 
ORNL Annual Health Physics Division Report for 1963, Technical Report \# ORNL 3492, K. Z. Morgan, Director, September 23, 1963

ORNL Annual Health Physics Division Report for 1968, Technical Report \# ORNL 4316, K. Z. Morgan, Director, October 3, 1968

Parrish, B. R.

Evaluation of external persontel monitoring devices and data for Oak Ridge National Laboratory epidemiological study

Master's Thesis, University of North Carolina, Chapel Hill, 1982

Payne, D., Reagan, J., and Wallace, P.

Data modeling of scientific data

Presentation at the International ORACLE Users' Conference

Miarni, Florida, October 2, 1991

Polednak, A. P.

Long-range studies of uranium workers and the Oak Ridge radiation worker population

In: The Medical Basis for Radjation Accident Preparedness

Edjtors: Hubner, K. F., Fry, S. A., 401-409, 1980A

Polednak, A. P.

Mortality among men occupationally exposed to phosgene in 1943-1945

Environ. Res. 22, 357-367 1980B

Polednak, A. P., and Frome, E. L.

Mortality among men employed between 1943 and 1947 at a uranium-processing plant

J. Occup. Med. 23(3):169-178, 1981

Polednak, A. P. and Hollis, D. R.

Mortality and causes of death among workers exposed to phosgene in 1943.1945

Toxicol. Indust. Health 1(2), 137-147 (1985)

Strom, D. J.

A strategy for assigning occupational radiation data from many facilities for use in epidemjological studjes

Ph.D. Dissertation, University of North Carolina at Chapel Hill, 1983

Strom, D. J.

Estimating individual and collective doses to groups with "fess than detectable" doses: a method for use in epidemiologic studies

Health Physics, Vol. 51(4), pp. 437-445, 1986 
Union Carbicle Corporation

Force and Turnover Report, Report 1856, and Annual Human Resources Reports, and Annual Personnel Reports, 1943 through 1984

U.S. Department of Heaith, Education, and Welfare, Public Health Service, National Center for Health Statistics

Eighth Revision International Classification of Diseases, Adapted for Use in the United States

ICDA, Volume 2, Public Health Service Publication No. 1693, Vol. 2, December 1968

West, C. M.

Description of the ORNL external monitoring program 1943-1961

June 1, 1992 Memo to D. L. Cragle

Center for Epidemiologic Research, Oak Ridge Institute for Science and Education

West, C. M.

Brief history of the Y-12 external monitoring program

June 7, 1993, Memo to D. L. Cragle

Center for Epidemiologic Research, Oak Ridge Institute for Science and Education

Wing, S., Shy, C. M., Wood, J. L., Wolf, S., Cragle, D. L., and Frome, E. L.

Mortality among workers at Oak Ridge National Laboratory: Evidence of radiation effects in follow-up through 1984

JAMA, 265(11), pp. 1397-1402, March 1991

X-10 Exposure Inventory, Center for Epidemiologic Research, Oak Ridge Institute for Science and Education

Y-12 Exposuse Irventory, Center for Epidemiologic Research, Oak Ridge Institute for Science and Education 


\section{APPENDIX A: SUBCOHORT FOR FACILITY COMPARISON ANALYSIS}

Entry in follow-up for the preliminary SMR analysis was 30 days after first hire by an Oak Ridge tacility. However, for all analyses except the preliminary SMR analysis the covariable length of employment was included and had two levels: one year or less and greater than one year. There were many short term workers, and it was desirable to limit the number of time-dependent variables whenever reasonable to make efficient use of computer resources. Therefore, for the facility comparison analyses, which included the four race/gender groups, a worker was entered into follow-up 365 days after first hire. Any workers who died or were lost to follow-up during the year after first hire were excluded from the subcohort for facility comparison analyses. Table At summarizes the number of individuals, deaths, and person-years lost by imposing a 365 day entry criterion on the cohort analysis. The remaining tables in this section provide information about this subcohort by race/gender group. 
Table A1

Impact of 365 Day Entry to Follow-up

\begin{tabular}{|l|c|c|c|c|c|c|c|c|}
\hline \multirow{2}{*}{} & \multicolumn{4}{|c|}{ Entry Hire + 30 Dars } & \multicolumn{3}{c|}{ Entry Hire + 365 Davs } \\
\cline { 2 - 10 } & $\begin{array}{c}\text { Total } \\
\text { Number }\end{array}$ & $\begin{array}{c}\text { Total } \\
\text { Deaths }\end{array}$ & $\begin{array}{c}\text { Total } \\
\text { Cancer } \\
\text { Deaths }\end{array}$ & $\begin{array}{c}\text { Total } \\
\text { Person- } \\
\text { Years }\end{array}$ & $\begin{array}{c}\text { Total } \\
\text { Number }\end{array}$ & $\begin{array}{c}\text { Total } \\
\text { Deaths }\end{array}$ & $\begin{array}{c}\text { Total } \\
\text { Cancer } \\
\text { Deaths }\end{array}$ & $\begin{array}{c}\text { Total } \\
\text { Person- } \\
\text { Ysars }\end{array}$ \\
\hline White males & 68,666 & 22,724 & 4,679 & $1,824,000$ & 67,197 & 22,590 & $\mathbf{4 , 6 7 3}$ & $1,761,950$ \\
\hline White females & 29,791 & 3,595 & 1,124 & 833,100 & 27,377 & 3,581 & $\mathbf{1 , 1 2 4}$ & $\mathbf{8 3 2 , 3 5 0}$ \\
\hline Nonwhite males & 4,233 & 1,121 & 202 & 82,700 & 3,909 & 1,106 & 201 & 82,600 \\
\hline Nonwhite females & $\mathbf{3 , 3 1 1}$ & 542 & 109 & 70,400 & 2,826 & 542 & 109 & 70,250 \\
\hline
\end{tabular}

\begin{tabular}{|c|c|c|c|c|}
\hline \multicolumn{5}{|c|}{$\begin{array}{c}\text { Table A2 } \\
\text { Distribution of Covariables by Race/Gender Groups }\end{array}$} \\
\hline & $\begin{array}{c}(67,197) \\
\text { White Males }\end{array}$ & $\begin{array}{c}(3,909) \\
\text { Nonwhite Males }\end{array}$ & $\begin{array}{c}(27,377) \\
\text { White Females }\end{array}$ & $\begin{array}{c}(2,826) \\
\text { Nomutice Femates }\end{array}$ \\
\hline \multicolumn{5}{|c|}{$\begin{array}{l}\text { Bitth cohort } \\
\text { Number of workers (\% of race/gender group) }\end{array}$} \\
\hline before $1 / 1 / 1900$ & $5,859(8.7)$ & $233(6.0)$ & $511(1.9)$ & $92(3.3)$ \\
\hline $1 / 1 / 1900-12 / 31 / 1909$ & $10,194(15.2)$ & $338(8.6)$ & $2,157(7.9)$ & $302(10.7)$ \\
\hline $1 / 1 / 1910-12 / 31 / 1919$ & $17,086(25.4)$ & $673(17.2)$ & $5,976(21.8)$ & $613(21.7)$ \\
\hline $1 / 1 / 1920-12 / 31 / 1929$ & $17,120(25.5)$ & $874(22.4)$ & $12,906(47.1)$ & $785(27.8)$ \\
\hline $1 / 1 / 1930+$ & $16,938(25.2)$ & $1,791(45.8)$ & $5,827(21.3)$ & $1,034(36.6)$ \\
\hline \multicolumn{5}{|c|}{$\begin{array}{l}\text { Length of employment } \\
\text { Number of workers (\% of race/gender group) }\end{array}$} \\
\hline$<1$ year & $23,880(35.5)$ & $1,632(41.7)$ & $11,928(43.6)$ & $1,460(51.7)$ \\
\hline 1 year + & $43,317(64.5)$ & $2,277(58.3)$ & $15,449(56.5)$ & $1,366(48.3)$ \\
\hline \multicolumn{5}{|c|}{$\begin{array}{l}\text { Paycode } \\
\text { Number of workers (\% of race/gender group) }\end{array}$} \\
\hline Monthiy & $10,023(15.0)$ & $358(9.2)$ & $751(2.8)$ & $63(2.2)$ \\
\hline Normonthly & $57,174(85.0)$ & $3,551(90.8)$ & $26,626(97.2)$ & $2,763(97.8)$ \\
\hline
\end{tabular}




\begin{tabular}{||l|c|c|c|c||}
\hline \multicolumn{5}{||c||}{ Table A3 } \\
\hline & $\begin{array}{c}(67,197) \\
\text { White Males }\end{array}$ & $\begin{array}{c}(3,909) \\
\text { Nonwhite Males }\end{array}$ & $\begin{array}{c}(27,377) \\
\text { White Females }\end{array}$ & $\begin{array}{c}(2,826) \\
\text { Nonwhite Females }\end{array}$ \\
\hline Years of employment & 6.9 & 5.9 & 3.3 & 3.3 \\
\hline Mean & 1.9 & 1.8 & 1.2 & 0.9 \\
\hline Median & & & & \\
\hline Years of follow-up & 26.2 & 20.2 & 24.5 & 23.9 \\
\hline Mean & 29.4 & 16.2 & 37.9 & 27.1 \\
\hline Median & & & & \\
\hline
\end{tabular}

\begin{tabular}{|l|c|c|c|c|c|}
\hline \multicolumn{7}{|c|}{ Table A4 } \\
\hline $\begin{array}{c}\text { Frequency } \\
\text { (Percent) }\end{array}$ & IEC & K-25 & Y-12 & ORNL & Total \\
\hline Nonmonthly & 20,041 & 21,497 & 9,018 & 6,618 & $\begin{array}{c}57,174 \\
(85.08 \%)\end{array}$ \\
\hline Monthly & 446 & 2,705 & 1,127 & 5,745 & $\begin{array}{c}10,023 \\
(14.92 \%)\end{array}$ \\
\hline Total & $\begin{array}{c}20,487 \\
(30.49 \%)\end{array}$ & $\begin{array}{c}24,202 \\
(36.02 \%)\end{array}$ & $\begin{array}{c}10,145 \\
(15.10 \%)\end{array}$ & $\begin{array}{c}12,363 \\
(18.40 \%)\end{array}$ & $\begin{array}{c}67,197 \\
(100.00 \%)\end{array}$ \\
\hline
\end{tabular}

\begin{tabular}{|l|c|c|c|c|c||}
\hline \multicolumn{6}{|c|}{ Length of Employment by Facility of First Hire (White Males) } \\
\hline $\begin{array}{c}\text { Frequency } \\
\text { (Percent) }\end{array}$ & TEC & K.25 & Y-12 & ORNL & Total \\
\hline $\begin{array}{l}\text { Greater than } \\
1 \text { year }\end{array}$ & 9,286 & 9,662 & 1,173 & 3,759 & $\begin{array}{c}23,880 \\
(35.54 \%)\end{array}$ \\
\hline I year or less & 11,201 & 14,540 & 8,972 & 8,604 & $\begin{array}{c}43,317 \\
(64,46 \%)\end{array}$ \\
\hline Total & 20,487 & $\begin{array}{c}24,202 \\
(36.02 \%)\end{array}$ & $\begin{array}{c}10,145 \\
(15.10 \%)\end{array}$ & $\begin{array}{c}12,363 \\
(18.40 \%)\end{array}$ & $\begin{array}{c}67,197 \\
(100.00 \%)\end{array}$ \\
\hline \hline
\end{tabular}




\section{Table A6}

Paycode by Facility of First Hire (Nonwhite Males)

\begin{tabular}{|l|c|c|c|c|c|}
\hline $\begin{array}{c}\text { Frequency } \\
\text { (Percent) }\end{array}$ & $\underline{\text { TEC }}$ & $\underline{\text { K-25 }}$ & $\underline{\text { Y-12 }}$ & $\underline{\text { ORNL }}$ & $\underline{\text { Total }}$ \\
\hline Nonmonthly & 1,080 & 982 & 707 & 782 & $\begin{array}{c}3,551 \\
(90.84 \%)\end{array}$ \\
\hline Monthly & 0 & 49 & 29 & 280 & $\begin{array}{c}358 \\
(9.16 \%)\end{array}$ \\
\hline Total & $\begin{array}{c}1,080 \\
(27.63 \%)\end{array}$ & $\begin{array}{c}1,031 \\
(26.38 \%)\end{array}$ & $\begin{array}{c}736 \\
(18.83 \%)\end{array}$ & $\begin{array}{c}1,062 \\
(27.17 \%)\end{array}$ & $\begin{array}{c}3,909 \\
(100.00 \%)\end{array}$ \\
\hline
\end{tabular}

Table A7

Length of Employment by Facility of First Hire (Nonwhite Males)

\begin{tabular}{||c|c|c|c|c|c|}
\hline $\begin{array}{c}\text { Frequency } \\
\text { (Percent) }\end{array}$ & $\underline{\text { TEC }}$ & $\underline{\text { K-25 }}$ & $\underline{\text { Y-12 }}$ & ORNL & $\underline{\text { Total }}$ \\
\hline $\begin{array}{c}\text { Greater than } \\
1 \text { year }\end{array}$ & 715 & 408 & 99 & 410 & $\begin{array}{c}1,632 \\
(41.75 \%)\end{array}$ \\
\hline 1 year or less & 365 & 623 & 637 & 652 & $\begin{array}{c}2,277 \\
(58.25 \%)\end{array}$ \\
\hline Total & $\begin{array}{c}1,080 \\
(27.63 \%)\end{array}$ & $\begin{array}{c}1,031 \\
(26.38 \%)\end{array}$ & $\begin{array}{c}736 \\
(18.83 \%)\end{array}$ & $\begin{array}{c}1,062 \\
(27.17 \%)\end{array}$ & $\begin{array}{c}3,909 \\
(100.00 \%)\end{array}$ \\
\hline
\end{tabular}


Table A8

Paycode by Facility of First Hire (White Females)

\begin{tabular}{|l|c|r|r|r|r|}
\hline $\begin{array}{c}\text { Frequency } \\
\text { (总rent) }\end{array}$ & TEC & $\underline{\text { K-25 }}$ & $\underline{\text { Y-12 }}$ & ORNL & Total \\
\hline Nonmonthly & 14,605 & 6,809 & 1,674 & 3,538 & $\begin{array}{c}26,626 \\
(97.26 \%)\end{array}$ \\
\hline Monthly & 8 & 159 & 60 & 524 & $\begin{array}{c}751 \\
(2.74 \%)\end{array}$ \\
\hline Total & $\begin{array}{c}14,613 \\
(53.38 \%)\end{array}$ & $\begin{array}{c}6,968 \\
(25.45 \%)\end{array}$ & $\begin{array}{c}1,734 \\
(6.33 \%)\end{array}$ & $\begin{array}{c}4,062 \\
(14.84 \%)\end{array}$ & $\begin{array}{c}27,377 \\
(100.00 \%)\end{array}$ \\
\hline
\end{tabular}

Table A9

Length of Employment by Facility of First Hire (White Females)

\begin{tabular}{||c|c|c|c|c|c|}
\hline $\begin{array}{c}\text { Frequency } \\
\text { (Percent) }\end{array}$ & $\underline{\text { TEC }}$ & $\underline{\text { K-25 }}$ & $\underline{\text { Y-12 }}$ & $\underline{\text { ORNL }}$ & $\underline{\text { Total }}$ \\
\hline $\begin{array}{c}\text { Greater than } \\
\text { 1 year }\end{array}$ & 7,542 & 3,021 & 251 & 1,114 & $\begin{array}{c}11,928 \\
(43.57 \%)\end{array}$ \\
\hline 1 year or less & 7,071 & 3,947 & 1,483 & 2,948 & $\begin{array}{c}15,449 \\
(56.43 \%)\end{array}$ \\
\hline Total & $\begin{array}{c}14,613 \\
(53.38 \%)\end{array}$ & $\begin{array}{c}6,968 \\
(25.45 \%)\end{array}$ & $\begin{array}{c}1,734 \\
(6.33 \%)\end{array}$ & $\begin{array}{c}4,062 \\
(14.84 \%)\end{array}$ & $\begin{array}{c}27,377 \\
(100.00 \%)\end{array}$ \\
\hline
\end{tabular}




\begin{tabular}{||c|r|r|r|r|r||}
\hline \multicolumn{7}{|c|}{ Table A10 } \\
\hline $\begin{array}{c}\text { Frequency } \\
\text { (Percent) }\end{array}$ & $\underline{\text { TEC }}$ & $\underline{\text { K-25 }}$ & $\underline{\text { Y-12 }}$ & ORNL & Tatal \\
\hline Nonmonthly & 1,469 & 535 & 313 & 446 & $\begin{array}{c}2,763 \\
(97.77 \%)\end{array}$ \\
\hline Monthly & 0 & 19 & 8 & 36 & $\begin{array}{c}63 \\
(2.23 \%)\end{array}$ \\
\hline Total & $\begin{array}{c}1,469 \\
(51.98 \%)\end{array}$ & $\begin{array}{c}554 \\
(19.60 \%)\end{array}$ & $\begin{array}{c}321 \\
(11.36 \%)\end{array}$ & $\begin{array}{c}482 \\
(17.06 \%)\end{array}$ & $\begin{array}{c}2,826 \\
(100.00 \%)\end{array}$ \\
\hline
\end{tabular}

Table A11

Length of Employment by Facility of First Hire (Nonwhite Females)

\begin{tabular}{||c|c|c|c|c|c|}
\hline $\begin{array}{c}\text { Frequency } \\
\text { (Percent) }\end{array}$ & TEC & $\underline{\text { K-25 }}$ & $\underline{\text { Y-12 }}$ & ORNL & Total \\
\hline $\begin{array}{c}\text { Greater than } \\
\text { 1 year }\end{array}$ & 977 & 199 & 90 & 194 & $\begin{array}{c}1,460 \\
(51.66 \%)\end{array}$ \\
\hline 1 year or less & 492 & 355 & 231 & 288 & $\begin{array}{c}1,366 \\
(48.34 \%)\end{array}$ \\
\hline Total & $\begin{array}{c}1,469 \\
(51.98 \%)\end{array}$ & $\begin{array}{c}554 \\
(19.60 \%)\end{array}$ & $\begin{array}{c}321 \\
(11.36 \%)\end{array}$ & $\begin{array}{c}482 \\
(17.06 \%)\end{array}$ & $\begin{array}{c}2,826 \\
(100.00 \%)\end{array}$ \\
\hline
\end{tabular}




\section{APPENDIX B: SUBCOHORT FOR DOSE-RESPONSE ANALYSIS}

The subcohort for dose-response analysis includes all white males from the study cohort who worked at ORNL or Y-12 for at least part of their employment in Oak Ridge nuclear tacilities. For the dose-response analyses follow-up began 365 days after first hire at either ORNL or Y-12. Table B1 summarizes the number of individuals, deaths, and person-years lost by imposing a 365 day entry criterion on the cohort for the facility comparison analysis. The remaining tables in this section provide information on the demographic and exposure data of this subcohort. Additional figures are also supplied to provide exposure data information by year and facility.

\begin{tabular}{||c|c|c|c|c|}
\hline \multicolumn{5}{|c|}{ Table B1 } \\
\hline & $\begin{array}{c}\text { Total } \\
\text { Number }\end{array}$ & $\begin{array}{c}\text { Total } \\
\text { Deaths }\end{array}$ & $\begin{array}{c}\text { Total } \\
\text { Cancer } \\
\text { Deaths }\end{array}$ & $\begin{array}{c}\text { Total } \\
\text { Person- } \\
\text { Years }\end{array}$ \\
\hline $\begin{array}{c}\text { Entering Follow-up 30 days after } \\
\text { hire by either ORNL or Y-12 }\end{array}$ & 28,770 & 4,821 & 1,138 & 629,636 \\
\hline $\begin{array}{c}\text { Entering Follow-up 365 days after } \\
\text { hire by either ORNL or Y-12 }\end{array}$ & 28,347 & 4,786 & 1,134 & 603,500 \\
\hline
\end{tabular}




\begin{tabular}{|l|c|}
\hline \multicolumn{2}{|c|}{ Table B2 } \\
\hline \multicolumn{2}{|c|}{ Distribution of Covariables } \\
\hline $\begin{array}{c}(28,347) \\
\text { White Males }\end{array}$ \\
\hline Birth cohort & $729(2.6)$ \\
\hline before 1/1/1900 & $2,190(7.7)$ \\
\hline $1 / 1 / 1900-12 / 31 / 1909$ & $5,059(17.8)$ \\
\hline $1 / 1 / 1910-12 / 31 / 1919$ & $7,221(25.5)$ \\
\hline $1 / 1 / 1920-12 / 31 / 1929$ & $13,148(46.4)$ \\
\hline $1 / 1 / 1930+$ & \\
\hline Length of employment & $5,064(17.9)$ \\
\hline$<1$ year & $23,283(82.1)$ \\
\hline 1 year + & \\
\hline Paycode & $20,538(72.3)$ \\
\hline Nonmonthly & $7,809(27.7)$ \\
\hline Monthly & \\
\hline
\end{tabular}

\begin{tabular}{||l|c|}
\hline \multicolumn{2}{||c|}{\begin{tabular}{c|} 
Table B3 \\
Average Years of Employment and Follow-Up
\end{tabular}} \\
\hline \multicolumn{2}{|l|}{$\begin{array}{c}\text { White Males } \\
(28,347)\end{array}$} \\
\hline Years of employment & 11.6 \\
\hline Mean & 7.5 \\
\hline Median \\
\hline Years of follow-up & 21.3 \\
\hline Mean & 22.4 \\
\hline Median
\end{tabular}




\begin{tabular}{|c|l|}
\hline \multicolumn{2}{|c|}{ Table B4 } \\
Distribution by Facility \\
\hline Facility & $\begin{array}{c}(28,347) \\
\text { Number of Workers (\%) }\end{array}$ \\
\hline ORNL only & $11,127(39.3 \%)$ \\
\hline Y-12 only & $8,525(30.1 \%)$ \\
\hline Multiple facilities & $8,695(30.6 \%)$ \\
\hline Total & 28,347 \\
\hline
\end{tabular}

${ }^{*}$ At least one of these facilities must be ORNL or Y-12.

\begin{tabular}{||c|c|c|c|c|}
\hline \multicolumn{5}{|c|}{ Dable B5 } \\
\hline & Recorded Dose & Lag 2 & Lag 10 & Lag 20 \\
\hline Total external dose (cSv) & 36,720 & 35,970 & 31,870 & 20,800 \\
\hline $\begin{array}{c}\% \text { of total recorded cose } \\
\text { for tntire study colhort }\end{array}$ & $(90.6)$ & $(88.7)$ & $(78.6)$ & $(51.3)$ \\
\hline Number of workers by cumulative external dose (\%) & & & \\
\hline$<1$ cSv & $21,561(76.1)$ & $21,739(76.7)$ & $22,550(79.5)$ & $24,397(86.1)$ \\
\hline$\geq 1$ to <5 cSv & $5,438(19.1)$ & $5,278(18.6)$ & $4,598(16.3)$ & $3,156(11.1)$ \\
\hline$\geq 5$ cSv & $1,348(4.8)$ & $1,330(4.7)$ & $1,199(4.2)$ & $794(2.8)$ \\
\hline mean cumulative dose (cSv) & 1.30 & 1.27 & 1.12 & 0.73 \\
\hline median cumulative dose (cSv) & 0.21 & 0.19 & 0.09 & 0 \\
\hline Quantiles (cSv) & & & & \\
\hline $100 \%$ & 461.87 & 461.87 & 461.74 & 461.20 \\
\hline $75 \%$ & 0.95 & 0.92 & 0.77 & 0.32 \\
\hline $25 \%$ & 0 & 0 & 0 & 0 \\
\hline $0 \%$ & 0 & 0 & 0 & 0 \\
\hline
\end{tabular}




\begin{tabular}{|c|c|c|}
\hline \multicolumn{3}{|c|}{$\begin{array}{c}\text { Table B6 } \\
\text { Distribution of Annual Internal Exposure Values }\end{array}$} \\
\hline & ORNL (1943-1984) & $Y=12(1947-1984)$ \\
\hline not monitored (\%) & $116,595(79.9)$ & $125,914(72.9)$ \\
\hline monitored but not exposed (\%) & $9,434(6.4)$ & $7,216(4.2)$ \\
\hline monitored and exposed (\%) & $19,979(13.7)$ & $39,600(22.9)$ \\
\hline Total & 146,008 & 172,730 \\
\hline not eligible for monitoring $(\%)$ & $13,439(9.2)$ & $7,060(4.1)$ \\
\hline eligible but not monitored (\%) & $103,156(70.7)$ & $118,854(68.8)$ \\
\hline monitored (\%) & $29,413(20.1)$ & $46,816(27.1)$ \\
\hline Total & 146,008 & 172,730 \\
\hline
\end{tabular}




\section{PERCENT OF ORNL WORKERS MONITORED}

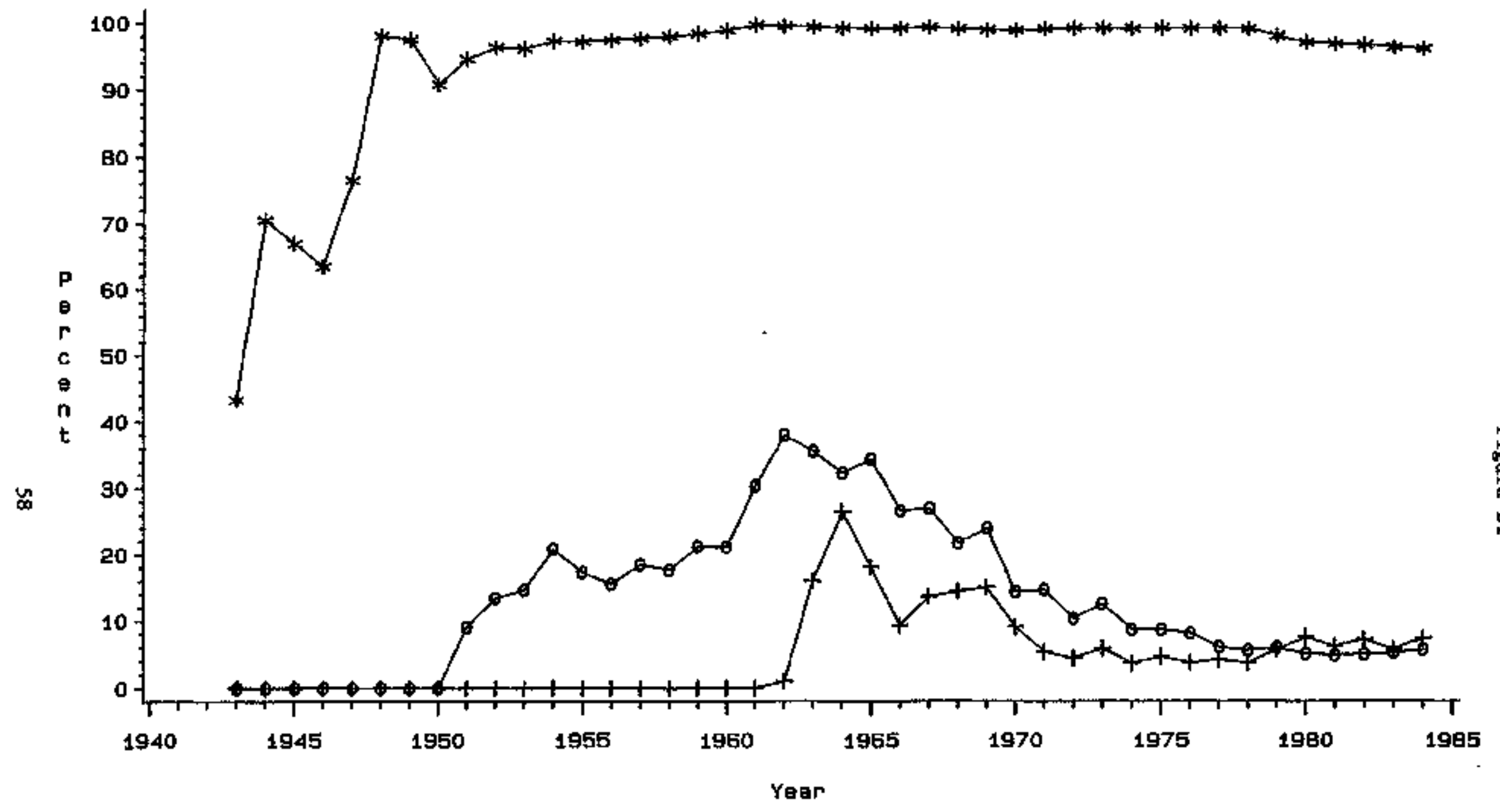

For ORNL from 1947 to 1951 there are somo annual doses of 0 in the raw dato files that were asalgned to workers who nover entered restricted areas and so were not octually monitored. Beginning in Novernber 1951 all ORML employees were monitored, regardless of access to rodiation areos. 


\section{PERCENT OF Y12 WORKERS MONITORED}

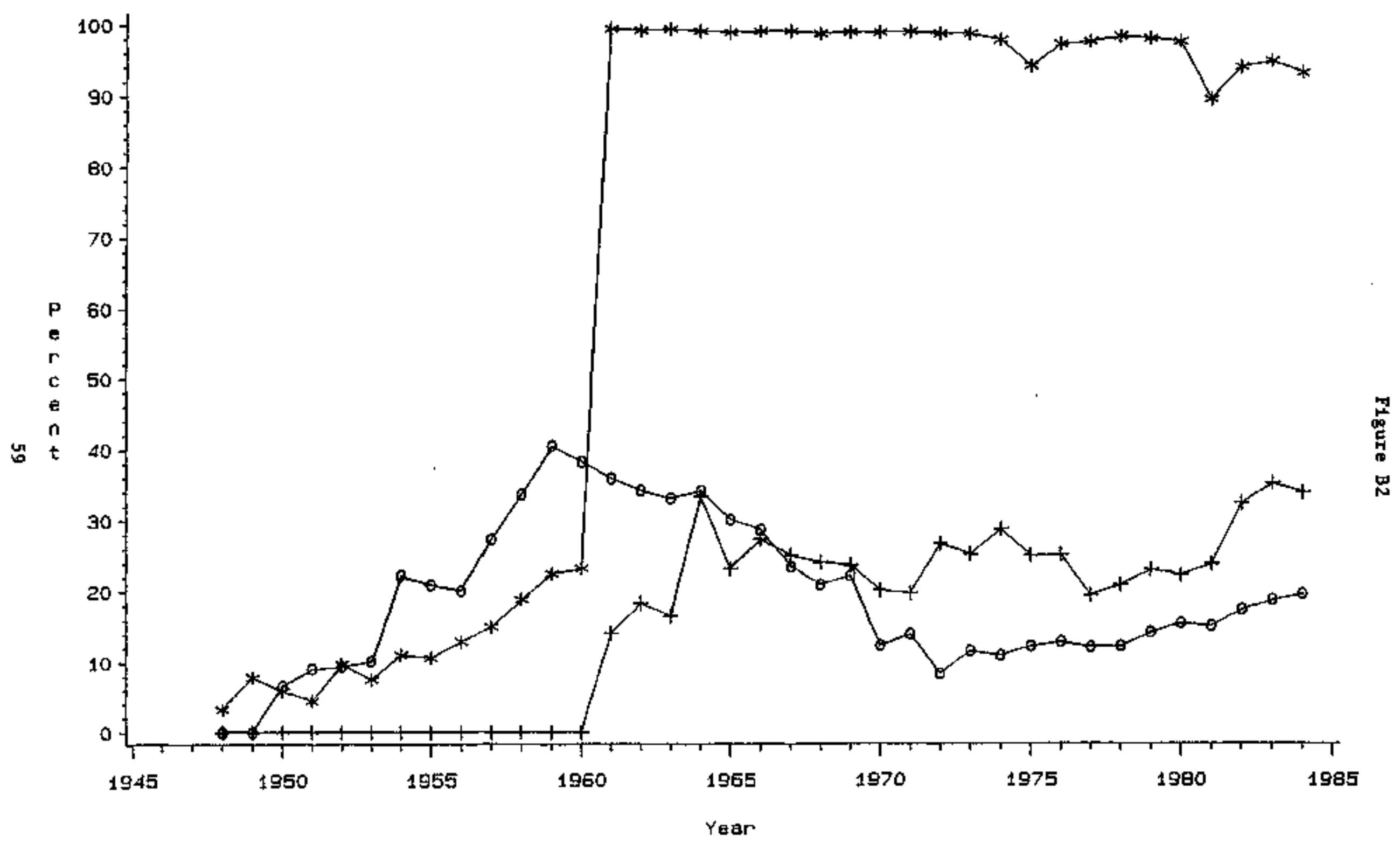

*** EXTERNAL MONITORING $\because+0$ URINALYSIS $+1+$ WHOLE BODY COUNT 
PERCENT OF ORNL WORKERS BY ANNUAL INTERNAL EXPOSURE INDICATOR

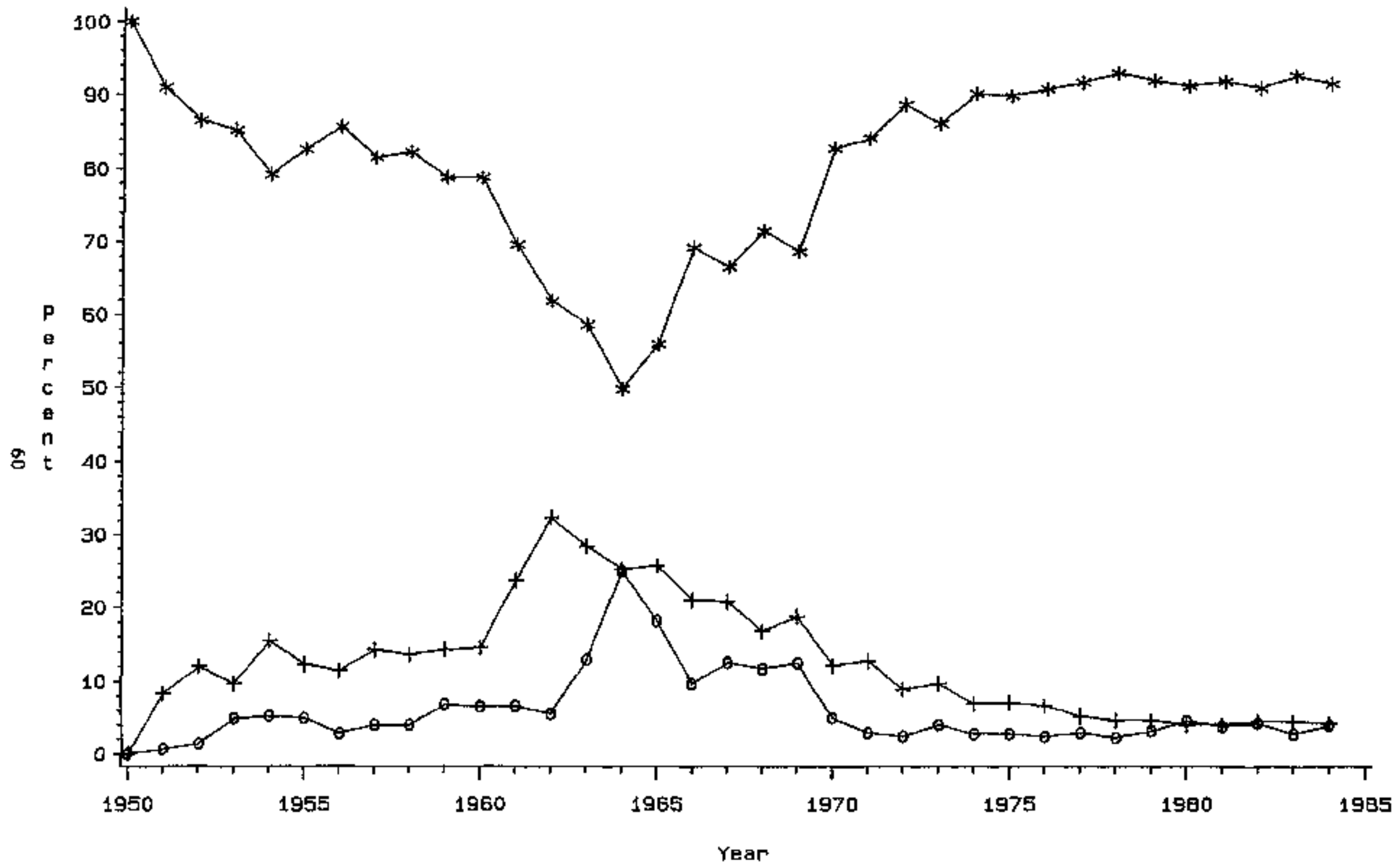


PERCENT OF Y12 WORKERS BY ANNUAL INTERNAL EXPOSURE INDICATOR

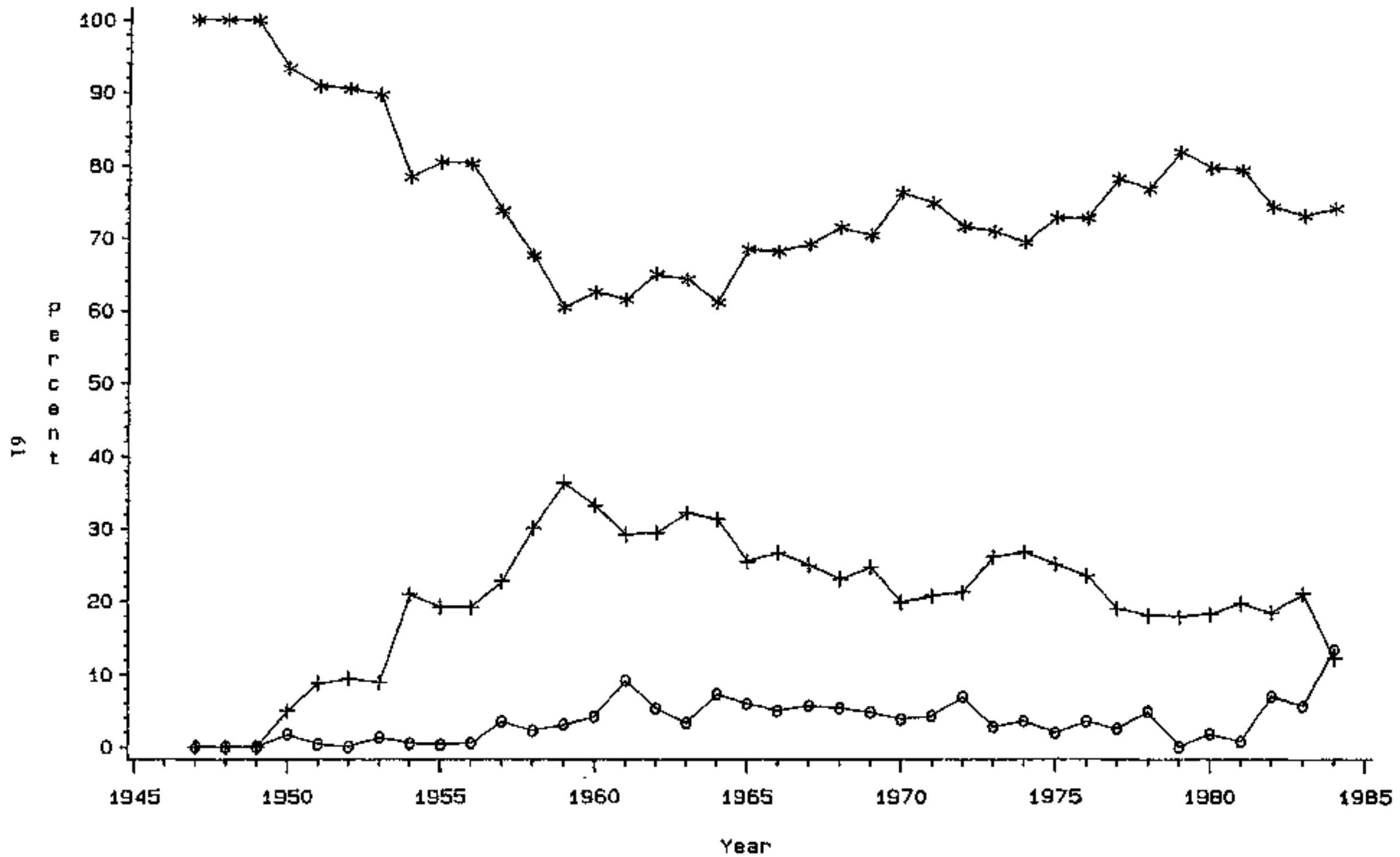

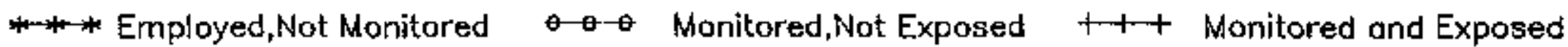




\section{PERCENT OF K25 WORKERS BY ANNUAL INTERNAL EXPOSURE INDICATOR}

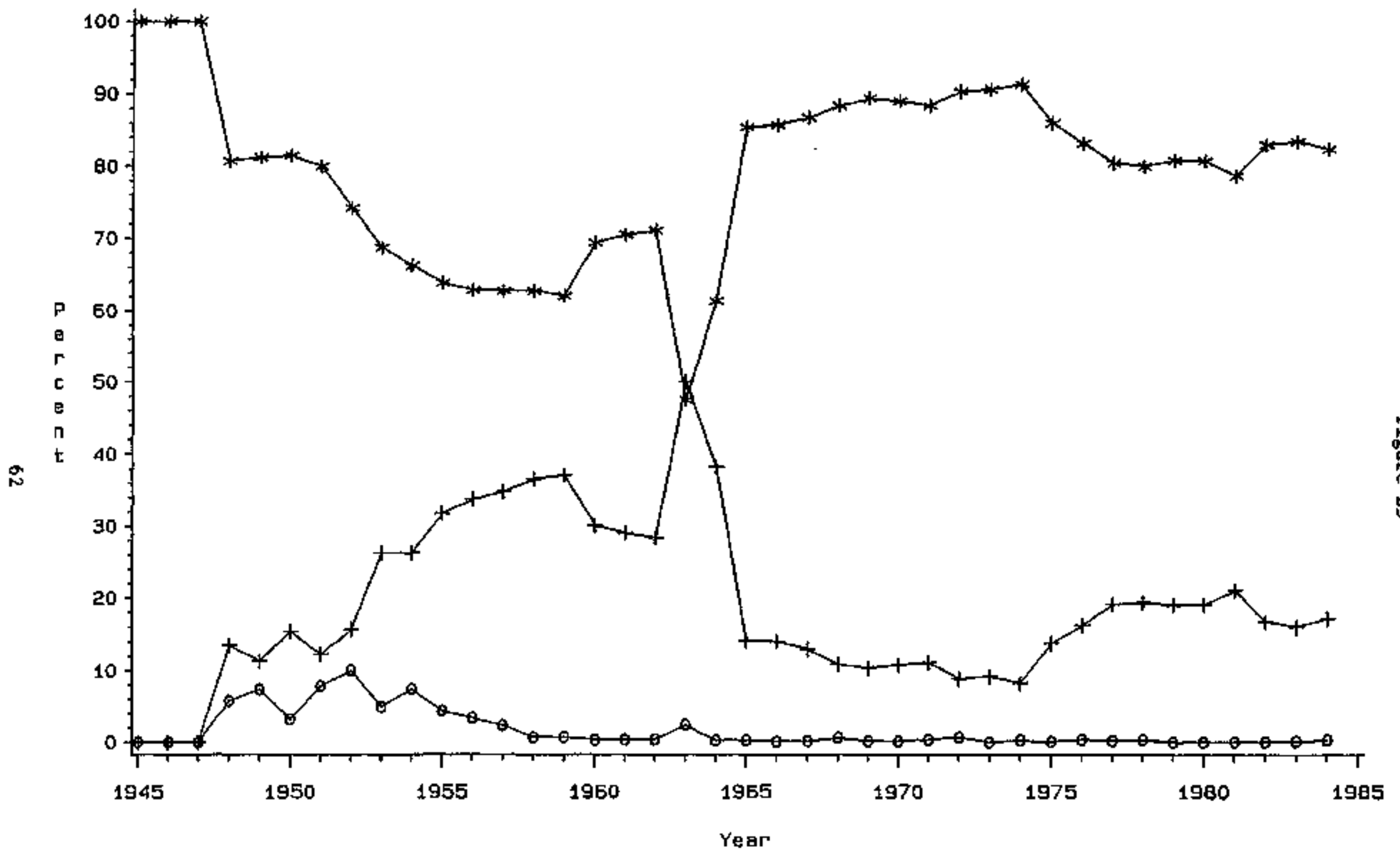

Ww- Employed, Not Monitored $\quad 0-0$ Monitored,Not Exposed $+\ldots+$ Monitored and Exposed 